\title{
Fra Stjepan M. Ivančić kao povjesničar
}

Koncem 19. i početkom 20. stoljeća među hrvatskim povjesničarima i kroničarima franjevaštva zaslužno mjesto zauzima franjevac trećoredac o. Stjepan Marija Ivančić (Cres, 28. kolovoza 1852. - Zadar, 8. travnja 1925.). Iako bez formalnoga povjesničarskoga obrazovanja, istaknuo se kao predani povjesničar redovničke zajednice kojoj je i sam pripadao - franjevcima trećorecima glagoljašima (Tertius Ordo Regularis $S$. Francisci) - te ćirilometodske baštine uopće. Objavio je brojne radove, publicirao diplomatička i druga vrela te sastavio Imenik preminulih redovnika samostanskog III. reda S. O. F. redodržave s. Jerolima u Dalmaciji, Kvarneru i Istri (1910.) i životopise trećoredskih autora koji su djelovali od 15. do 19. stoljeća (Nešto o hrvatsko-glagolskim piscima samostanskih Trećoredaca, 1911.). Kao krunu svoga dugogodišnjega rada zaokružio je izdavanjem iznimno vrijednog i temeljitog djela pod naslovom Povjestne crte o samostanskom III. Redu sv. O. Franje po Dalmaciji, Kvarneru i Istri i poraba glagolice u istoj redodržavi (Zadar, 1910.). U ovom se radu prikazuju njegova tiskana djela te iznose i vrednuju njegovi manje poznati i neobrađeni rukopisi i spisi, koji se čuvaju u Arhivu Provincije franjevaca trećoredaca glagoljaša u Zagrebu i drugdje. Posebno se prikazuje njegovo rukopisno djelo Cronologium seu Historica monumenta Tertii Regularis Ordinis de Poenitentia Sancti Patris Francisci, koje se čuva u Arhivu Generalne kurije franjevačkoga Trećega reda u Rimu (Archivio della Curia Generalizia TOR / Archivio generale del Terz' Ordine Regolare di S. Francesco, Roma).

Koncem 19. i početkom 20. stoljeća među povjesničarima i kroničarima franjevaštva na hrvatskim povijesnim prostorima zaslužno mjesto zauzima franjevac trećoredac o. Stjepan Marija Ivančić, glagoljaš, crkveni povjesničar, pisac i propovjednik. ${ }^{1}$ Rođen u Cresu, 28. kolovoza 1852., umro u Zadru, 8. travnja $1925 .{ }^{2}$, svojim je uzornim redovničkim životom i znanstvenim radom zadužio

1 Za različite oblike pomoći prilikom pisanja ovoga rada na ovome mjestu zahvaljujem, nažalost, danas već pokojnima, fra Petru Runji (1938. - 2014.) i fra Anđelku Badurini (1935. - 2013.) te kolegama doc. dr. sc. Ivanu Botici (Staroslavenski institut, Zagreb), vlč. Kristijanu Kuharu (Staroslavenski institut, Zagreb), dr. sc. Vinku Kovačiću (Filozofski fakultet Sveučilišta u Zagrebu), fra Mirku Miškoviću (Provincija franjevaca trećoredaca glagoljaša, Zagreb) i Pauli Raguž (Znanstvena knjižnica Dubrovnik).

2 RADIĆ 1963d: 66-70; Isti 1963e: 90-94; GREGOV I MILČETIĆ 1985: 183-190; PETROVIĆ 2005: 125-126; PAPONJA 2010: 244-245; Isti 1980; Isti 2001: 316-317. Usp. i SPINČIĆ 1925: 114; Isti 1926: 117; MARKOVIĆ 1975: 379; STRČIĆ 2007: 77; SOKOLIĆ 2008: 109. 
svoju Provinciju franjevaca trećoredaca glagoljaša (Samostanski III. Red sv. o. Franje ili Treći samostanski red sv. Franje od pokore; Tertius Ordo Regularis de Poenitentia S. Francisci, tj. Tertius Ordo Regularis S. Francisci-TOR), ali poviše toga i hrvatsku historiografiju, iako u njezinu okrilju zapravo do danas nije dobio zasluženo i uopće priznato mjesto. ${ }^{3}$

U Arhivu Provincije franjevaca trećoredaca glagoljaša u Zagrebu čuvaju se listovi s Ivančićevim memorandumom: „Fratar Stjepan M. Ivančić, Trećega samostanskoga reda sv. Franje od pokore, naučitelj sv. bogoslovlja, u Rimskoj kuriji bivši redo-vrhovni vijećnik i proškrbnik, a u ovoj Hrvatskoj Redo-državi istarsko-dalmatinskoj redo-državnik i u Gospodinu sluga“".

Trećorecima je pristupio 23. listopada 1865. godine u gradu Krku, gdje je tada bila njihova novootvorena škola za redovnički pomladak, tj. sjemenište, koju je otvorio tadašnji provincijal, zaslužni o. Josip Dujmović (1833. - 1884.). ${ }^{5}$ Tada je obukao redovnički habit i uzeo redovničko ime Stjepan (civilno ime bilo mu je Ivan). ${ }^{6}$ Posinovljen samostanu sv. Mihovila u Zadru u novicijat je stupio 4. listopada 1868. u samostanu sv. Marije na Glavotoku. ${ }^{7}$ U Zadru je 1870. završio gimnaziju, koju su tada u Nadbiskupskom sjemeništu držali isusovci, te 1874. bogosloviju pri Velikom (Latinskom) sjemeništu. Za svećenika je zaređen 10. siječnja, a Mladu misu slavio je 17. siječnja 1875. u Zadru. Tom je prilikom mladomisniku veliku čast učinio njegov subrat fra Dragutin Antun Parčić (1832. - 1902.), posvetivši mu prepjev 1. pjevanja Pakla - Inferno Danteove mudropojke (spjeva) Božanstvena komedija - La Divina Commedia. To je djelo Parčić preveo - ponašio za pokus - i tiskao kao svoj prvi uradak u vlastitoj tiskari na Glavotoku (Serafinski tisak). ${ }^{8} \mathrm{U}$ posveti je, između ostalog, uputio ove riječi mladomisniku: Prepoznav u Tebi ljubav prema materinskom jeziku i iskru pjesničkoga duha evo prilikom ovoga za Te pametna dneva odpravljam Ti u pohode ovaj spomenik. Ako i nije posve nabožna sadržaja; ali je početak one divne Mudropojke (...) - te u zadnjoj rečenici mladom

Usp. ANTOLJAK 1992: 48-50; Isti 2004: 46-48. Na citiranim se mjestima Ivančić spominje samo u bilješkama, odnosno navode se njegove dvije knjige (Povjestne crte o samostanskom III. Redu sv. o. Franje po Dalmaciji, Kvarneru i Istri i poraba glagolice u istoj redodržavi, 1910. i Nešto o hrvatsko-glagolskim piscima samostanskih Trećoredaca, 1911.) kao literatura.

4 Arhiv Provincije franjevaca trećoredaca glagoljaša, Zagreb: Građa i rukopisi za povijest Reda i Provincije (Ivančić i Zec).

5 GREGOV 1990: 107.

6 BOTICA, KOVAČIĆ I KUHAR 2015: 39, 149-150 (dok. br. 187): „I seguenti giovani, affigliati a vari Conventi della Provincia cioè: (...) Ivančić Giovanni da Cherso col nome Stefano“.

7 BOTICA, KOVAČIĆ I KUHAR 2015: 152-153 (dok. br. 190): „I candidati poi Novizzi sono: $1^{\circ}$ il Reverendo Fra Stefano Ivančić, figlio del Nostro Convento San Michele, Zara (...)“.

8 BONEFAČIĆ 1903: 14; IVANČIĆ 1910: 198; BOLONIĆ 1965: 24; GOSTL 1998: 49, 82-83. U pogledu traduktološke vrijednosti ovoga Parčićeva djelca v. TOMASOVIĆ 1994: 68-77, $79,83$. 
fratru jasno apostrofirao - Zaodjeni se hrabrošću da budeš koristan Redu i Rodu. ${ }^{9}$ Ovo je Ivančić - vrijedi to napose istaknuti - kroz cijeli svoj život vjerno slijedio.

U Redodržavi/Provinciji franjevaca trećoredaca glagoljaša obavlja različite službe. Tako je bio tajnik Provincije od 1878. do 1883. U to doba pada i njegovo prvo objavljeno djelo, a riječ je o prijevodu jedne talijanske knjige na hrvatski jezik pod naslovom: Mjesec dana na nauku kod svetoga Josipa ili kratka zabavna štivenja kroz mjesec ožujak o životu svetaca, tiskane u Zadru $1878 .{ }^{10}$

Velika je čast ukazana Ivančiću, koji je 27. lipnja 1880. u Rimu u crkvi sv. Jeronima - na 1000. obljetnicu papina dopuštenja uporabe staroslavenskog u liturgiji $\left(880 .-1880\right.$.) - otpjevao svečanu sv. misu na staroslavenskom jeziku. ${ }^{11}$

Učitelj (lektor) kasnije je naučitelj (doktor) sv. bogoslovlja franjevačkih trećoredskih novaka u Zadru, na Školjiću (Galevcu), u gradu Krku i Glavotoku, i to od 1883. do 1888., kada biva imenovan redo-vrhovnim vijećnikom (generalnim vijećnikom - definitorom) Reda u Rimu. ${ }^{12}$ Od 1897. do 1903. bio je redo-vrhovni proškrbnik (generalni prokurator) Reda u Rimu. ${ }^{13}$ Budući da je tadašnji general (generalni ministar) trećoredaca o. Pijo Cecca ${ }^{14}$ preminuo, prema franjevačkim konstitucijama, upravo je Ivančić trebao vršiti tu službu do izbora novoga generala - no, to mu je bilo onemogućeno jer „,svojom prirodnom animoznošću nije našao saglasnosti u talijanskim članovima Kurije“ (I. Radić). ${ }^{15}$

Za vrijeme svoga boravka u Rimu (1888. - 1903. $)^{16}$ - uz sve druge zadaće i poslove - bio je na ruku i od velike pomoći Parčiću prilikom rada, priprema i tiskanja njegova životna djela, glagoljskog Misala $^{17}$ na crkvenoslavenskom jeziku hrvatske redakcije: Rimbski Misalb slavênbskimb ezikomb prêsv. G. N. Urbana Papi VIII povelêniemb izdanb Missale Romanum Slavonico idiomate ex decreto sacrosancti Concilii Tridentini (1893.). ${ }^{18}$

\footnotetext{
9 BADURINA 1993a: 162; Isti 1993b: 162.

10 O pitanju autorstva prijevoda, budući da taj podatak nije zabilježen na samoj knjizi, niti u bibliografiji (usp. MAŠTROVIĆ 1949: 118), vidi GREGOV I MILČETIĆ 1985: 190.

11 BURIĆ 1966: 72.

12 „God. 1888. imenovan je naš fra Stjepo generalnim definitorom. Kažem 'imenovan', jer je stanje našega reda onda bilo veoma teško, da ne rečem kritično. Ujedinjena revolucionarna Italija, god. 1880, oborila je papinsku državu, zaposjela i naše samostane, rastjerala redovnike. Malo po malo su se oni u grupicama ovdje ondje grupirali. Kapitul se nije mogao održavati, pa je zato Sveta Stolica imenovala i postavljala članove generalne kurije“ (RADIĆ 1963d: 66). Usp. i LUCONI 1944: 199.

13 LUCONI 1944: 202; RADIĆ 1963d: 67.

14 Usp. LUCONI 1944: 203.

15 RADIĆ 1963d: 67.

16 LUCONI 1935: 282; PAZZELLI 1958: 299, bilj. 6.

17 IVANČIĆ 1910: 197, bilj. (*); BOLONIĆ 1965: 32, bilj. 84; TANDARIĆ 1993: 81-82.

18 PARČIĆ 1893.
} 
Ivančić je bio i u kontaktu s don Franom Bulićem, kojem je jednom zgodom dojavio kako je, vezano uz glagoljicu i staroslavensko bogoslužje, protiv njega u Rim pisao njegov vlastiti splitsko-makarski biskup Filip Franjo Nakić. ${ }^{19}$ No, taj je odnos bio opterećen i činjenicom da se Bulić zauzimao da se novi glagoljski Misal tiska transkribiran latiničkim slovima, na što je burno reagirao Parčić ${ }^{20}$, kome je Ivančić bio jedan od glavnih pomoćnika.

Sudjelovao je na dvama međunarodnim kongresima Trećega svjetovnog reda sv. Franje (Congresso internazionale del Terz'Ordine Secolare), i to 1895. u Assiziju i 1900. u Rimu. ${ }^{21}$ Na potonjem je pred papom Lavom XIII. držao govor: „Medju ostalimi govorio je i naše gore list, poznati propovjednik Cresanin otac Stjepan Ivančić, o zadaći Trećeg Reda, Trećoredaca, da spase sviet od moralne propasti u koju pada, molitvom, ljubavlju i zajedničkim djelovanjem za posvećenje društva“. ${ }^{22}$

Ivančić je bio istaknut i posebno hvaljen propovjednik ${ }^{23}$ po Kvarneru i Dalmaciji - podjednako na hrvatskom, a po nekima čak još više na talijanskom jeziku ${ }^{24}$ - te se govorilo da nije bilo crkve na potezu od Kopra do Kotora, a da u njoj nije držao propovijed fra Ivančić. ${ }^{25}$ Priredio je i Hrvatski Bogoslužbenik ili sbirka jutrnja i večernja glavnih svetkovina preko godišta i obrednih molitava i raznih pjesama koje se običavaju po hrvatskih župah u Dalmaciji i susjednih zemljah. Ta je molitveni priručnik doživio čak tri izdanja: prvo 1882., drugo 1893. i treće izdanje 1907. ${ }^{26}$ Opširnu, pak, Propovied na čast sv. Cirila i Metoda, držanu u Zadru 1881., tiskom je objavio 1886. u glasilu katoličkih propovjednika Duhovni govornik, koji je izlazio u Madjarevu (tj. Novomarofu), a uređivao ga je župnik Josip Lach. ${ }^{27}$

9 JURIŠIĆ 2011: 1020, bilj. 19.

20 KOVAČIĆ 1985: 176-178.

21 LUCONI 1935: 282-283. Naslov prvog izlaganja bio je „Il Terz’Ordine e la stampa e la scuola“, a drugog „Leone XIII Terziario Francescano“.

$22 \quad * * *$ Medjunarodni sastanak Trećaredaca sv. Frana 1900: 159.

23 Usp. ***Častnomu otcu Stjepanu Ivančiću propovjedniku reda Male bratje u znak štovanja i harnosti na koncu korizmenog propoviedanja ovu pjesmu posvećuje creski puk 1880: 35 (ovdje je Ivančić zabunom nazvan fratrom reda Male braće - Ordo fratrum minorum); ***Veleučenom gospodinu Stjepanu Ivančiću otcu trećega reda prezaslužnom nam ovogodišnjem koriz. propovjedniku pri njegovu odlazku. Pjesma. Komižani. Komiža na koncu Korizme 1883; ***Prijatelji: Mnogo poštovanom Otcu Stjepu Ivančiću korizmenomu prepovjedniku u Dubrovačkoj Stolnoj Crkvi 1901: 3. RADIĆ $1963 \mathrm{~d}: 68$.

25 Navodimo ovdje jedan primjer iz 1904. u gradu Krku: „Propovijedao je (...) provincijal trećoredaca mnogočasni otac Stjepan Ivančić. Propovijedi su bile obzirom na radne dane dobro posjećene i pozorno su se slušale, jer su bile uprav krasne“ (***Procesija s novim kipom Majke Božje u Krku 1904: 188).

26 Zadar: Upraviteljstvo „Narodnoga lista“.

27 Spomenimo da je autora ovih redaka fra Božo Sučić, gvardijan franjevačkog trećoredskog samostana sv. Pavla Pustinjaka na Galvecu (Školjiću), upozorio na propovijedi i neke druge spise koji se čuvaju u tome samostanskom arhivu i knjižnici. To bi, dakako, trebalo posebno istražiti. Tim više što su upravo neka Ivančićeva djela nastala upravo u tome samostanu. 
Druga polovina 19. i početak 20. stoljeća u našim su krajevima bili posebno obilježeni pitanjem glagoljaštva, kako u crkvenim, tako i u političkim krugovima ${ }^{28}$, a čemu je poseban pečat dala enciklika Grande munus (Veliko poslanje, 1880.) pape Leona XIII., izdana povodom 1000. obljetnice djelovanja Svete braće Ćirila i Metoda. ${ }^{29}$ Dakako da Ivančić nije ostao sa strane u tim gibanjima. Iako je zapravo za vrijeme najžešćih polemika službovao u Rimu, ondje je bio na ruku svima onima koji su se zalagali za potonje. Tako je, nakon pokrajinskog sastanka u Splitu 6. srpnja 1902. - Za glagolicu, na kojem je priređen tekst predstavke, koji je 1903. delegacija na čelu sa splitskim načelnikom Vickom Milićem uputila papi u vidu zaštite glagoljice i staroslavenskog bogoslužja te osobno došla u lipnju 1903. u Rim. Tom prilikom: „Rodoljub fratar Ivančić bio je u velike pri ruci deputaciji“", koju je uputio gdje, što i kako da traži u Vatikanu. ${ }^{30}$ Delegacija je uz pomoć Ivančića sretno primljena u audijenciju kod pape Leona XIII., koji će, nažalost, već idući mjesec, u srpnju 1903., preminuti. No, glagoljica - kao vanjski izraz žive vjere sviju Hrvata katolika - ovim je činom, tj. prijemom kod svetog Oca bila „u našoj povjesti znameniti dogadjaj, prvi utjecajem svjetovnjaka, za obranu naše svetinje". 31

Nadalje, Ivančić je autor ,prigodničarskih izjava, obrana, poslanica i zahvala istaknutim i zaslužnim ljudima u promicanju hrvatske kulture i dobrobiti“ (Iv. Petrović). ${ }^{32}$ Povodom smrti fra Serafina Belamarića (1869. - 1907.), provincijala Male braće konventualaca, u vlastitoj nakladi izdaje nekrolog-oznanjenje: Plači $i$ tuguj o creski puče nad preranom smrti tvoga dobrotvora m. p. o. Serafina Belamarića provincijala Male braće konventualaca. U potpisu stoji: „Na ime creskih kopača fr. Stjepo M. Ivančić cresanin Provincijal Trećoredskih franjevaca u Zadru“.33

Kao provincijal, odnosno redo-državnik u Hrvatskoj Redo-državi istarsko-dalmatinskoj (od 1904.) - izabran na tu dužnost nakon povratka iz Rima ${ }^{34}$ - Ivančić se zauzeo za obnovu i izgradnju onih samostana gdje se nalazila redovnička mladež: „U mjesecu listopadu, ufajuć se u Božju pomoć, pođoh u Đakovo k’ velikom hrvatskom Dobročinitelju Biskupu Jurju J. Strossmayeru, te mi pokloni na dar, obzirom

28 Usp. zbornik radova STANČIĆ 1990, napose BRATULIĆ 1990a: 385-400; Isti 1990b: 377-390; MILINOVIĆ 2004: 237-321 (izvorno objavljeno 1880.); PRODAN 1900a; Isti 1900b; Isti 1904; IVANIŠEVIĆ 1930; KOVAČIĆ 1993: 449-459; BRATULIĆ 1995; ŽUBRINIĆ 1996: 267-303; DIKLIĆ 2003: 49-58; VELČIĆ 2015: 75-100.

Usp. RELJANOVIĆ 2001: 355-374.

Za glagolicu. Pokrajinski sastanak u Splitu 1902 [i. e. 1903]: 47.

Za glagolicu. Pokrajinski sastanak u Splitu 1902 [i. e. 1903]: 49, 51.

PETROVIĆ 2005: 125-126.

IVANČIĆ 1907. Opis oznanjenja v. u MAŠTROVIĆ 1979: 436 (br. 1014).

„Na prov. kapitulu g. 1904, izabran je o. Stjepan za provincijala. Tako je on sa strane provincije dobio zadovoljštinu, za 'eventualne nepravice' koje je doživio u Rimu“ (RADIĆ 1963d: 67). 
što smo mi njegovatelji Glagolice, dvije tisuće kruna (2000). Iz Đakova pođoh do Zagreba, te i preuzv. Nadbiskup Juraj Posilović pokloni mi za istu svrhu, za potrošak naime što ga uložili za kupnju starog Apela u Zadru i u podignuće drugog poda na Školjiću na uhar Mladeži, liepi dar od tisuću kruna (1000). Sakupih poviše kod preč. zagrebačkog kaptola drugih tri stotine kruna (300) dočim mi stotinu (100) darova sam hrvatski ban grof Pejačević (... “. ${ }^{35}$ je Strossmayer svoje obećanje izvršio - doznačio novčanu pomoć provinciji za školovanje pomlatka - Ivančić mu se uime svoje redovničke zajednice zahvalio prigodnicom objavljenom u Glasniku Biskupije bosanske i sriemske te u Vrhbosni: „Preuzvišenom pragospodinu Josipu Jurju Strossmayeru, prilikom skorog dara Trećem samostanskom redu sv. Franje u Dalmaciji i Istri. Kano gojitelju glagoljice“. ${ }^{36}$

Želeći unaprijediti stanje svoje „mile redo-države“, obraća se svojoj subraći poslanicom, koja je ujedno tiskana u Zadru 1906. Pod naslovom: Poslanica svojoj miloj braći, redovnicima samostanskoga Trećeg reda sv. otca Frane Redo-države Dalmacije i Istre Ivančić - tada provincijal, odnosno redodržavnik - u Poslanici ističe zavjet redovnikâ Bogu da će održavati Božje zapovijedi i zapovijedi Majke Crkve, odnosno da su obećali poslušnost, čistoću, siromaštvo. ${ }^{37}$ Ističe kakav treba biti redovnik i kako treba poštovati redovničku stegu. Poslušnost franjevačkom redu: zajedničko stanovanje, bez osobnoga novca (ako dobiju novac, moraju ga predati Poglavaru), bez pokretnina ili nekretnina, dužni su ,pred Bogom i ljudima“ neprestano učiti. Iznosi povlastice sačuvanog staroslavenskog bogoslužja i molitve Časoslova na „glagolski““. ${ }^{38}$ Da je upravo ovo potonje, a što je Ivančić posebno naglasio, bilo predmetom i idućih desetljeća $u$ franjevaca trećoredaca (napose u pogledu traženja svoga posebnog identiteta) dobro svjedoče tekstovi fra Šime Vladovića o proslavi Ćirilometodskog jubileja (863. - 1963.) u Provinciji franjevaca trećoredaca glagoljaša ${ }^{39}$ i fra Ljudevita Gregova $O$ našem glagolizmu ${ }^{40}$

35 GREGOV 1990: 33.

36 IVANČIĆ 1904a: 172; Isti 1904b: 383. Ta je prigodnica objavljena i u knjizi Prigodnice biskupu Strossmayeru (2005: 101), gdje je o Ivančiću, u kratkim biografijama autorâ (2005: 136), doslovce napisano samo ovo: IVANČIĆ, STJEPO. Franjevački provincijal.

37 U toj poslanici obrazlaže i potiče na obdržavanje zavjeta siromaštva i na redovničku zajednicu itd.: „Dužnost mi je ovdje dozvati svima na pamet, što je i koliko se u ovom pogledu brinuo i trudio blagopokojni i velezaslužni Redo-Državnik O. Josip Dujmović, koji je već godine 1864. zajedno sa redodržavnom Skupštinom mnogo toga utanačio, a napose obzirom na sv. Uboštvo, da se uvede po Redo-državi podpuno obslužuje Pravila, Ustanova i Papinskih Odredaba; tako da se on može svim pravom smatrati Preustrojiteljem ove naše Redodržave. Njegove je stope sliedio i zaslužni starina Prečastni Otac Carevko Buić, koji je Otcem maldane svih nas i odraslih i mladjih, te koji je neprestano pelio, da se po svim Samostanima uvede troključna škrinja. Za točno obsluženje ove osobite naredbe naših Ustanova, brigao se je takodjer svesrdno i moj Predšastnik Preč. današnji Redovrhovni Obskrbnik O. Daniel Zec“ (IVANČIĆ 1906: 14-15). IVANČIĆ 1906.

39 VLADOVIĆ 1964a: 56-61; Isti 1964b: 76-79.

40 GREGOV 1965a: 62-66; Isti 1965b: 108-111. 
U trećoj godini službe provincijala, koncem lipnja 1906., Ivančića je za vrijeme duhovnih vježbi koje je držao benediktinkama u gradu Krku „udarila kap“, tako da je odlučio odstupiti iz službe. ${ }^{41}$

Godine 1912. Ivančić je proslavio svoj šezdeseti rođendan. Tom su prilikom mnogi čestitali slavljeniku, primjerice, list Naša sloga sljedećim riječima: „Šezdesetogodišnjicu svoga života navršuje danas veleč. O. Stjepan Ivančić, trećoredac u samostanu svoga reda u Zadru. Veleč. O. Ivančić poznat je u našim stranama ne samo kao odličan propovjednik nego i kao vrstan pisac i odličan branitelj naše crkvene svetinje, naše drevne glagoljice. Mnogobrojnim čestitkama prijatelja i štovatelja veleč. O. Stjepana pridružujemo se i mi živom željom da bi nam ga svevišnji još dugo uzdržao na životu živa i zdrava“.42

Nakon odreknuća red-državne uprave - provincijala Ivančić je boravio u Zadru, odnosno na Školjiću, na kojem se dobro oporavio. ${ }^{43}$ Međutim, „Rapalski ugovor, koji mu odnosi zavičaj, djeluje na nj poput novoga srčanog udara“"(A. Badurina) ${ }^{44}$ Fra Petar Runje, pišući o svijetlim likovima u Provinciji franjevaca trećoredaca glagoljaša tijekom 20. stoljeća, donosi sljedeće svjedočanstvo: „Stjepan Ivančić, u svojoj ljubavi prema domovini - pričao nam je otac Kerubin (Sišul - op. a.) - da je pred cijelom katedralom na glas izjasnio se na monsinjorove riječi da je Zadar odvijeka talijanski energično uzviknuo: Nikada! - i protestno sa štapom u ruci napustio katedralu. Nisu mu zamjerili ni Talijani jer su znali njegovu ljubav i odanost prema svima, a svoj jezik i narod cijenio je kao zjenicu oka“". ${ }^{45}$

Njegove posljednje godine života ovako opisuje njegov subrat fra Ignacij Radić (1876. - 1965.): „Teška ga žalost pritisnu okupacijom Dalmacije sa strane Talijana, koja u crno zavi sve naše rodoljube, kad mrtvačko zvono Zadarske katedrale najavi nacionalnu smrt Zadru i okolici. Rapalo...! Sin creskog hrvatskog 'kopaca' ostane sam bez znanaca i prijatelja u već otudjenom gradu, i kao Jeremija u Babiloniji, oronuli starac dovukao bi se svakog jutra do stare obale, sjedio sat vremena $\mathrm{u}$ kafani 'Al Vaporetto', popio bi crnu kafu koju bi mu koji prijatelj platio, da se zatim pognute glave vrati u sveti Mihovil i zatvori u svojoj sobici i zaplakao“. 46

$\overline{41}$ IVANČIĆ 1910: III. Prema pisanju fra I. Radića, takvu situaciju, odstupanje i tri godine potom izbor novoga provincijala Ivančić je teško prihvatio: „Priznajemo, da su njegove ambicije bile donekle povrijedjene, te bi on kadgod, i ne samo u užem krugu svoje braće stao 'galamiti'; ali, koliko ga poznajemo nije podržavao neku stalnu odvratnost bilo spram koga. Brzo je sve zaboravljao. Uopće je spram svih htio biti dobro raspoložen, pravi kavalir, u srcu veledušan, trajne zle namjere nije podržavao niti širio kakvu propagandu za sebe“ (RADIĆ 1963d: 68).

$42 \quad * * *$ Razne primorske viesti 1912: 3 .

43 „Prilično se je na Školjiću oporavio. Naši djaci vozikali su ga od Ugljana do Kukljice, od Preka do Sukošana, na lokarde, kanjce, morske maške i druge ribe. Već od mladosti ljubio je ribarski šport" (RADIĆ 1963d: 68).

45 RUNJE 2007: 260.

46 RADIĆ 1963d: 68-69. 
Dana 18. siječnja 1925. u Zadru proslavio je svoj zlatni jubilej-50. godišnjicu misništva: „Crkva je bila prepuna naroda. Hrvati i Talijani su mu na koncu čestitali““ ${ }^{47}$

Smrt je Ivančića zatekla u Zadru 8. travnja 1925. Pokopan je na samostanskom groblju na Školjiću (Galevcu), uz dvojicu velikana: o. Josipa Dujmovića i don Ivu Prodana. ${ }^{48}$ Njegova franjevačka duhovnost i jednostavnost možda se najbolje očituje u riječima koje je zapisao 1910. na kraju Predgovora Imeniku preminulih redovnika, osvrćući se na svoj rad i trud oko izrade toga nekrologa: „Za sav moj trud i novčani trošak, obilna bit će mi nagrada, ako se moja braća sjete mene u molitvi, a po smrti izgovore: Pokoj i. t. d.“49

\section{$I$.}

Iako bez formalnog povjesničarskog obrazovanja, ali visokog intelekta, fra Stjepan M. Ivančić istaknuo se kao predani povjesničar redovničke zajednice kojoj je i sam pripadao - franjevcima trećorecima glagoljašima te uopće ćirilometodske baštine, ali iznad svega kao revni promicatelj staroslavenskog bogoslužja i glagoljskog pisma u Dalmaciji.

Surađivao je s hrvatskim slavistima i povjesničarima, a u političkom pogledu pripadao je pravaškom pokretu u Dalmaciji pod vodstvom don Ive Prodana (1852. - 1933.). ${ }^{50}$ „Kao samouk povjesničar“ - prema riječima Iv. Petrović - ,pridružio se hrvatskim proučavateljima ćirilometodske baštine", kao što su F. Rački, I. Kukuljević Sakcinski, M. Mesić, I. Berčić, I. Črnčić, I. Tkalčić, T. Smičiklas, V. Jagić, D. A. Parčić, I. Milčetić i dr. ${ }^{51}$

Važno je istaknuti da je Ivančićev interes za povijest još od mladih dana bio potaknut suradnjom s fra Dragutinom Antunom Parčićem i tadašnjim provincijalom o. Josipom Dujmovićem. ${ }^{52}$ Prema pisanju fra Ignacija Radića, on je već kao mladomisnik počeo proučavati Redodržavni/Provincijski arhiv. ${ }^{53}$ Suradnja s Parčićem i u domovini i kasnije u Rimu bila mu je vrlo važna, napose prilikom rada na glagoljskom Misalu. Vrijeme provedeno u Rimu Ivančić je dobro iskoristio za svoja istraživanja, skupljanje i prepisivanje građe te konzultiranje literature, posebice one koja se tiče trećoredaca u Europi i drugdje po svijetu.

\footnotetext{
Isto: 69.

48 Isto: $69-70$.

49 Imenik preminulih redovnika 1910: Nekoliko rieči predgovora (bez paginacije).

50 Usp. BADURINA 1993a: 164; Isti 1993b: 164.

51 Usp. PETROVIĆ 2005: 125.

52 PAPONJA 2010: 244.

53 RADIĆ 1963d: 66.
} 
U historiografskom je, pak, pogledu Ivančić autor nekoliko važnih djela te niza manjih članaka, publicirao je diplomatička i druga vrela. Stoga je posvećen istraživanjima povijesti franjevačkoga Trećega reda i slavenskog bogoslužja, koji je jedini u Hrvatskoj, odnosno u Dalmaciji i Istri baštinio i njegovao glagoljanje i glagoljicu kako u liturgiji, tako glagoljicu kao pismo i u svakodnevnoj uporabi. „Afirmacija povijesnih i kulturnih vrjednota, napose glagolizma kao hrvatske posebnosti, bili su odlučujućim čimbenicima u obrani hrvatskih nacionalnih interesa, posebice nakon Rapallskoga ugovora 1920., kojim su s hrvatskim nacionalnim teritorijem izgubljeni i samostani franjevačke provincije na Cresu, Lošinju i u Zadru“. ${ }^{54}$ No, razne druge obveze, poglavito različite upravljačke dužnosti u provinciji, ispriječile su se Ivančiću u tomu pravcu, pa se on tek usputno mogao baviti historiografskim radom. Prve je radove stoga objavio tek 1887., u svojoj 35. godini.

Nakon povratka iz Rima dolazi u Zadar, gdje biva izabran za provincijala, i to od 1904. do 1906./1907., kada je zbog bolesti odstupio. Razdoblje je nakon toga za njega bilo iznimno plodno i o tome želimo upravo ovdje progovoriti.

\section{II.}

Prvo Ivančićevo historiografsko djelo, a kojim je, dakako, privukao određenu pozornost stručnjaka, bilo je Poraba glagolice kod redovnika III. reda sv. Franje po Dalmaciji, Istri i Kvarneru, tiskano u Zadru 1887. Na svega 58 stranica teksta malog formata kroz 14 poglavlja donosi rezultate mahom vlastitih istraživanja povijesti franjevaca trećoredaca, njihovih začetaka, pojedinaca i samostanskih zajednica te života i uporabe glagoljice u Dalmaciji, Kvarneru i Istri kroz stoljeća. Riječ je zapravo o seriji članaka koji su se iste godine objavljivali u Prodanovoj Katoličkoj Dalmaciji. Pisac je svoje djelce posvetio: „Miloj redovskoj učećoj mladeži na pouku i bodrenje“. Autor se u tekstu i u bilješkama poziva na relativno brojne izvore i dostupnu literaturu (Š. Milinović, G. F. Cupilli, M. V. Batinić, F. Bordoni, I. Črnčić, G. Cubich, M. Pavlinović, I. Kukuljević-Sakcinski i dr.).

Prvom rečenicom čitatelja upućuje na glavnu temu svoga rada, a ta je uporaba glagoljice kod trećoredaca: „Jedan izmedju osobitih povlastica, kojom se svim pravom ponosi trećoredska dalmatinska Država, jest, što ona ćak od svoga ustanovljenja obavlja bogoslužje staroslovenskim jezikom“ (str. 3). No, ona se „takodjer rabila u svih unutrnjih poslovih redovske države“ (str. 20). Upozorava kako, nažalost, u samostanskim arhivima nije uvijek uspijevao pronaći tražene isprave, kao na primjer odobrenje Sv. Stolice trećorecima da mogu slobodno glagoljati, tj. koristiti se tom ,riedkom povlasticom“. Temeljna Ivančićeva teza u ovoj knjižici jest da su trećoreci odmah nakon dolaska u Zadar polovinom 13. stoljeća prihvatili

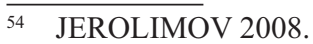


staroslavensko bogoslužje i glagoljicu. Ističe važnost rukopisâ, od kojih najviše žali za propalom zbirkom dokumenata koje je o. fra Karlo Radić (o. 1710. - 1766.) prikupio 1765. i čuvao u Zadru: „Documenta ex archivio s. Pauli in scopulo, ubi reperiuntur antiqae memoriae civitatis Jadrae, et ex archivio s. Joannis Baptistae Jadrensis; scripturae huc apportatae ex aliis coenobiis Dalmatiae et Istriae, ut ex anotationibus et indice P. Caroli Radich Jadrensis“"(str. 21). S druge, pak, strane vrlo se oštro odnosi prema Šimi Ljubiću, kojega kritizira zbog iznesenih sudova o fra Benediktu Mihaljeviću (1768. - 1855.) i drugome. Posebno je, pak, interesantna ova Ivančićeva paralela između latinskoga i staroslavenskoga: „Ovdje nije govora o prednosti jezikâ, ili da s pretjeranosti, štogod suprot latinici rečemo. Ne. Ovaj nam jezik sasvim potrebit za današnju našu svećeničku naobrazbu; njemu red je, da budemo vješti: ali učenje i posjed ovoga ne prieči staroslovenskomu, kao što ne prieči da se ovim kod nas bogoslužje svagdano glagolicom obavlja“"(str. 51). Na nekoliko se zadnjih stranica u cijelosti donosi govor veleučenog Ivana Dominika Stratika, prije novigradskog pa hvarskog biskupa, što ga je ovaj u pohvalu staroslavenskog bogoslužja kanio uputiti trećorecima za vrijeme njihova provincijskog sabora u istarskom Novigradu 1783. (str. 52-58). Iako skromna opsega, knjižica Poraba glagolice puna je brojnih vrijednih podataka i vrijednosnih ocjena.

Iste je godine u mjesečnik za obću prosvjetu-Smotra Ivan Milčetić izrazio svoje zadovoljstvo što je Ivančić,,izdao svoju radnjicu i u posebnoj knjižici, čim će ugoditi svakomu prijatelju prošlosti hrvatske“ te kaže da je „pisac zadahnut pjesničkim oduševljenjem za slovjensku liturgiju u svome radu, te je bio rad pokazati, kako je njegov red uvijek njegovao glagolicu, i potaknuti mladje da ne zaostanu za svojim predšasnicima“" ${ }^{55}$ U nastavku Milčetić predlaže kako bi bilo dobro da Ivančić tiska i sve isprave o uporabi glagoljice među trećorecima, a na koje se poziva u svojem radu. Naime, Parčić je Milčetiću usmeno priopćio da Ivančić ima takvu zbirku spremnu za objavu jer su ovako isprave na koje se poziva za nas ,„pô zakopano blago“. Također izjavljuje da bi Jugoslavenska akademija znanosti i umjetnosti bila novčano spremna poduprijeti takvo izdanje. ${ }^{56}$ Milčetić posebno ističe nekoliko važnih točaka prinosa koje proizlaze iz knjižice Poraba glagolice. To su novi podaci o fra Stjepanu Beliću, fra Antunu Juraniću i fra Benediktu Mihaljeviću te nove bibliografske vijesti, npr. o glagoljskom Misalu, o knjižici Spovid općena. U zaključku, nakon što je svesrdno preporučio tu knjižicu, Milčetić ovako kaže u pohvalu Ivančića: „Dok imade u zaslužnom franjevačkom redu ovako žarkih rodoljuba hrvatskih, ne će za cijelo isčeznuti naša liturgija; nju brani sa svim zanosom g. Ivančić, koji zbog svog rodoljublja mora boraviti u samotnom krčkom Glavotoku mjesto da bude u Zadru, gdje bi mogao dostojno zauzimati stolicu staroslovenštine u bogosloviji. G. Ivančić (Cresanin) darovit čovjek i revan propovjednik; a kako

\footnotetext{
55 ***J. M. 1887: 370. Napomena: Možda inicijal treba biti I. M., tj. Ivan Milčetić.

$56 * * *$ J. M. 1887: 371
} 
je mlad i prijatelj nauke, ne će ovo biti jamačno zadnja njegova radnja“‘. ${ }^{57} \mathrm{No}$, uz opravdanu pohvalu, Milčetić upućuje i opomenu mladom Ivančiću kako „ne treba da bude, uznoseći sve i svakoga u svom redu, onako papren, kako jest u životu Mihaljevićevu protiv zaslužnog akademika Ljubića“. 58

U prilog važnosti toga djela govori i činjenica da se njime koristio i don Luka Jelić prilikom izrade svojih izvora: Fontes historici liturgiae Glagolito-Romanae a XIII ad XIX saeculum (Veglae, 1906.). ${ }^{59}$

Puno godina kasnije to se Ivančićevo djelo našlo u središtu pozornosti jedne polemike. Naime, 1964. s. Marija Agnezija Pantelić objavila je opsežnu studiju, koja se ovećim dijelom temelji na njezinoj prethodno obranjenoj doktorskoj disertaciji, pod naslovom Glagoljski kodeksi Bartola Krbavca. ${ }^{60}$ Ocjenjujući tu važnu radnju, Rafo Bogišić pohvalio je autoricu i njezinu studiju, u kojoj su donesene brojne nove spoznaje i zaključci. ${ }^{61}$ Međutim, na to se - kako na samu autoricu, tako još više na samoga recenzenta - vrlo kritičkim tonom osvrnuo Zvonimir Kulundžić u tekstu Još o „putovima glagoljizma“. Gdje je naučna istina ${ }^{92}$ Kulundžić prije svega zamjera Bogišiću da ne poštuje „naučnu istinu“ jer autorici M. A. Pantelić pripisuje tri zasluge koje nisu opravdane. To su, kako je konstatirao Bogišić sljedeće: I. „Krasnopisac“ i minijator Bartol Krbavac, do sada je u nauci bio nepoznat; II. Živo središte i pravi rasadnik glagoljske pismenosti bila je okolica Zadra, sa susjednim Ninom; III. Lika i Krbava ,prije katastrofalne bitke bila je kulturni glagoljaški centar... Sve određenije ukazuje se vizija jednog kraja, koji je... pod vlašću glagoljici blagonaklonih Frankopana i Kurjakovića, u jednom vremenu imao rukovodeću ulogu u hrvatskoj kulturi““ ${ }^{63}$ Nećemo ovdje prepričavati tu polemiku, već želimo samo reći da, unatoč Kulundžićevu žestokom napisu i neopravdanim objedama prema ovim istaknutim istraživačima hrvatske književne i kulturne prošlosti (a posredno najviše prema Vjekoslavu Štefaniću ${ }^{64}$ ), njegov odgovor na postavljenu drugu točku Kulundžić upravo pronalazi u Ivančićevoj knjižici Poraba glagolice. Stoga piše: „Historijska činjenica da je Zadar sa svojom okolicom bio 'rasadnik pismenosti' - nije nikakvo novo otkriće, nego nešto što je nauci već odavno dobro poznato i notorno, jer je to iscrpno dokazao

\footnotetext{
***J. M. 1887: 371.

$\mathrm{Na}$ istome mjestu.

JELIĆ 1906: (XV.) 29, 38, 39; (XVIII.) 12, 57, 60, 66; (XIX.) 60.

PANTELIĆ 1964: 5-98. Ponovljeno u Ista 2013: 175-246.

BOGIŠIĆ: 1965: 4.

62 KULUNDŽIĆ: 1965: 2. Glavne naglaske te polemike ponovio je Z. Kulundžić i u svojoj knjizi Tragedija hrvatske historiografije: o falsifikatorima, birokratima, negatorima itd--- itd--- $h r$ vatske povijesti (1970a: 188, 191; Isti 1970b: 188, 191).

63 KULUNDŽIĆ: 1965: 2.

${ }^{64}$ Usp. i odgovor Vj. Štefanića - „Kulundžić o putovima glagoljizma“ (ŠTEFANIĆ 1965).
} 
Stjepan Ivančić u svojoj knjizi Poraba glagolice (... ${ }^{\text {“ }}{ }^{65}$ Tako su Ivančić i njegovo djelo - posredstvom jedne polemike - došli u središte pozornosti i znanstvenika i javnosti osamdesetak godina nakon objavljivanja.

Za vrijeme boravka u Rimu, više iz nužde, ali podjednako iz žarke želje da ospori pokušaj uskraćivanja prava Hrvatima na rimski Zavod sv. Jeronima (Collegium Sanctus Hieronymi Illyricorum in Urbe), Ivančić se, iako nije bio član Zavoda, našao usred glasovite tzv. „svetojeronimske afere“ 1901.

Potaknut svim tim događajima, iste godine objavljuje knjigu na talijanskom jeziku La questione di s. Girolamo dei [!] Schiavoni in Roma in faccia alla storia e al diritto ed il breve di S. S. Leone XIII ,,Slavorum Gentem “ (Pitanje Sv. Jeronima Slavenskoga u Rimu u vidu povijesti i prava i Breve Sv. o. p. Lava XIII. „Slavorum gentem“). Ne želeći ulaziti u opis toga velikog međunarodnog političkog i crkvenog spora, kojem je do danas posvećen lijep broj radova ${ }^{66}$, želimo samo konstatirati da je Ivančić svojim pisanim radom i javnim nastupom pridonio hrvatskoj stvari u Rimu, a što je kasnije imalo i određenih reperkusija na njega samoga. Neovisno o tomu što se u literaturi mogu naći ponešto različiti podaci, npr. da je tu knjigu danonoćno pisao dva tjedna, odnosno da ju je u roku od jednog ili dvaju mjeseca publicirao, ostaje činjenica da je knjiga napisana, priređena i tiskana u vrlo kratkom vremenu. To je jedino Ivančićevo djelo kojim on izlazi iz krugova franjevačke historiografije i ulazi u opću crkvenu i političku povijest. Riječ je o opsežnoj knjizi, koju je sam Ivančić okarakterizirao kao opuscolo (djelce ili brošura) - iako na ukupno čak 386 stranica sadrži tri cjeline: I. Un pò di storia; II. Documenti; III. Breve ,, Slavorum gentem “ e telegrammi di felicitazioni dalla Dalmazia, Istria e Bosnia i kao prilog jedan višestruko presavijen list s faksimilom povijesne karte iz 1660. od A. Buffalinija, na kojoj su pokrajine čiji pitomci-Hrvati ${ }^{67}$ imaju pravo na Zavod označene grbovima: Dalmacija, Hrvatska, Slavonija i Bosna. Nakon naslovnice ti su grbovi također ponovljeni na prikazu sv. Jeronima. Inače, Josip Pazman, prvi rektor modernog Zavoda, bio je Ivančiću od pomoći prilikom priređivanja onoga dijela knjige u kojem su objavljeni brojni telegrami iz Dalmacije, Istre i Bosne u korist obrane hrvatskih prava na Zavod. ${ }^{68}$

U Našoj slogi od 13. rujna 1901. Ivančić je bio primoran obznaniti dvojezičnu talijansko-hrvatsku izjavu povodom provale nekih Dalmatinaca, nastanjenih u

\footnotetext{
65 KULUNDŽIĆ: $1965: 2$.

66 Usp. prije svega opsežan zbornik radova BOGDAN 2001, a posebice radove KOVAČIĆ 2001a: 17-98; Isti 2001b: 99-124; potom JELIĆ 1902a; Isti 1902b; KISIĆ 1902; TUMPIĆ 1943: 340349; MAGJEREC 1953a; 1953b; KOKŠA 2001; BURIĆ 1971: 91-158; MILOVČIĆ 1990: 165-178; KATIČIĆ 1999: 171-188; STRECHA 1995: 158-189; Isti 1997: 169-213; GRIJAK 2001: 321-369.

GRIJAK 2001: 340.
} 
Rimu, u Zavod sv. Jeronima u Rimu. Pod optužbom da je javno izrekao ,prokletstvo“ nad pojedinim Dalmatincima, ovako se obranio: „Mučao sam do sada, a mučao bi bio i unapried ob onom što pišu rimske liberalne i slobodnozidarske novine, kao Tribuna, Patria, Capitale, Capitan Fracassa, o meni sad popu sad fratru u poznatom dogodjaju slovinskoga sv. Jeronima. Dapače, razgovarajuć se o silnim prećerivanjima i nizkim klevetama, nabačenim na moju siromašnu osobu, ja sam se s mojim prijateljima samo smijao te sam se skoro uznio, videći se bez moje zasluge postavljenim $u$ isti red, $u$ kojemu se nahodi i Papa, i austrijski poklisar, i hrvatski biskupi Strosmajer i Stadler te rektor zavoda dr. Pazman, proti kojim se rigalo i jošte se riga uvriede i pogrde. Ali nakon toga, što u uredničtvu lista L'Osservatore romano površno pročitah zadarski list Dalmata, moje staro poznanstvo, koji je prenio u kratko, neznam da li iz Tribune ili iz Patrie viest, da sam ja, prosvjedujući proti silovitim nazovi-dalmatinskim otmičarima izrekao prokletstvo - ja Vas proklinjem - i da su zato creski načelnik, načelnik moga rodnoga mjesta - dr. Petris, i načelnik Malog Sela, u komu sam dobro znan, ako se nevaram dr. Vidulich, obuzeti najneprirodnijim gnjevom, prosvjedovali proti meni čestitajuć Alačeviću i drugim 'Dalmatincima', dužnost moja i savjest svećenika i propoviednika nalažu mi, da progovorim. Nepobitna je istina, da sam poslije razgovora sa drom. Pazmanom, kojemu kratiše ulazak, meni i plemenitomu mladiću i prijatelju momu gosp. grofu Franu Salimei, plemićkom stražaru papinom, pristupio na vrata dvorane, koju su bili zaposjeli Alačević i družina, mojom običnom otvorenošću i jakim glasom uskliknuo: Ja prosvjedujem u ime Kvarnera i hrvatske Istre proti vašoj nasilnoj otimačini. Ali neizrekoh ni onda, ni sutra dan ni nikada - ja vas proklinjem - ili sličan izraz, u kojemu bi po viesti Dalmate bilo prokletstvo u ime Istre proti Dalmatincima. Kao propoviednik ja sam blagosivljao i moje Cresane i Lušinjane jedne i druge stranke, a pozivljem za svjedoka plemenitoga grofa Salimei i samoga dra. Pazmana, jer ja imadem oblast, da blagosivljem, ali da proklinjem to nisam nikada imao, a budući da je Dalmata čitan i u Zadru i u gradovima dalmatinskim, gdje sam ja i hrvatski i talijanski propoviedao u Trogiru, Splitu, Dubrovniku, Kotoru, Prčanju, Perastu, Dobroti, Mulu, Komiži, Pagu pak i na Rieci, Korčuli, Rabu, Krku, Malom Selu i Cresu, domovini mojoj, - radi dostojanstva moga svećeničkoga i misionarskoga značaja, svečano izjavljujem, da viest o prokletstvu nije drugo nego podla kleveta, posve izmišljena od liberalnih i slobodnozidarskih rimskih novina (koje tako jako ljube Papu i svećenstvo) te ovim javno pozivljem gg. Pierotića, Bonaviu i Dobrečića, koji su prisustvovali činu i s kojima sam se pravdao, ako se ne varam, još dne 30. i 31., ako imaju i mrvu poštenja neka izjave, da li sam ja ikako i ikada izustio rieč ili smisao prokletstva. Ako su pak radi mojega prosvjeda proti bučnoj i nasilnoj otimačini slovinskoga zavoda sv. Jeronima, ovršenom sa strane nekoliko dalmatinaca, nastanjenih u Rimu, prosvjedovali opet na njihov način načelnici maloselski Vidulich i creski dr. Petris, držim takodjer i ja, kao sin hrvatskoga 
naroda i austrijski podanik, da imam barem pravo kao i oni, da se u ime moga zavičaja, gdje je hrvatska većina i gdje su takodjer Moisé i Keršići i Petrići bili jednoć Hrvati, ili ako im je draže, Slovinci iliti Ilirci, da se u ime moga ljubljenoga Cresa, u prvom redu katoličkog i velikom Papi Lavu XIII., pravom otcu naroda, odanog grada, da se jednoć kao istarski Hrvat pridružim cieloj Dalmaciji i svemu hrvatskomu narodu, koji je napućio naše krajeve prosvjedujuć glasno proti nasilju i podloj otimačini nazovi-Dalmatinskih Talijana, kako ciela poštena i pravedna Italija, a š njome svi pošteni ljudi i cieli sviet osudjujuć onaj divljački čin, nedostojan čeljadi, koja se poziva na djedovsku uljudbu i koja bi htjela da joj u žilama teče plemenita latinska $k r v{ }^{\prime \prime} .{ }^{69}$

Fra Ignacij Radić, više od pola stoljeća kasnije, ovim je riječima skicirao tu problematiku: „(...) iskrsnu pitanje Zavoda sv. Jerolima, kojeg je Papa Lav XIII bio proglasio Hrvatskim zavodom: Pro gente Croatica. Protiv tog naziva nastane silna buka sa strane talijanske iredente. Nije ona birala sredstva da papinu odluku osujeti. Došlo je do oštrih pa i ručnih napada. Umješao se je i naš Ivančić, galamio je i protestirao, grlato i bučno. Kad sve to nije pomoglo, za desetak dana noću, napisa brošuru, pod imenom: 'La questione di s. Girolamo in Roma'. S vratiju Zavoda skinut je natpis 'Pro Gente Croatica', ali je zavod ostao u rukama Hrvata pod protektoratom Svete Stolice“. ${ }^{70}$

Također je važno navesti službeni dopis tadašnjeg provincijala o. fra Danijela Zeca od 20. listopada 1901., koji je razaslan po samostanima Provincije: „Javljamo tom č. Samostanu da u hajdučkom činu učinjenomu od Dalmatinskih bezbožaca u zavodu sv. Jeronima u Rimu i protiv Breveu sv. O. Pape. Naš Vlč. o. Ivančić, član naše Istarsko Dalmatinske Države, naš Vrhovni Prokurator Reda u Rimu priskočio na obranu Prava gori označenog Zavoda, potaknut od Uzoritog Stožernika Ser Vanutellia. I zbilja Preč. O. Ivančić u mjesec dana zgotovio djelce od 250. stranica na obranu istog zavoda, i tom prigodom imao osobitu milost eda bude primljen na posebnu privatnu Audijenciju kod Sv. O. Pape Leona XIII, s kojim imao sreću zadržati se preko četvrt sata. U to sretno doba isprosi Papinski Blagoslov za cijelu Našu Milu Državu i za dragu našu mladež koja mora da bude naslonom budućem napretku. Na riječi Preč. o. Ivančića sv. o. mu odvrati - Si benedico volontieri tutti quelli che intendete voi, e che il Signor li prosperi - Evo svima javljamo eda bude svima na utjehu i radost, da sv. otac podjelio svima Apoštolski Blagoslov““. ${ }^{71}$

Knjiga La questione di s. Girolamo iste je godine tiskana čak u dvama izdanjima u rimskoj tiskari Battarelli. Razlika je između njih samo u tome što je u drugom

69 IVANČIĆ 1901: 4.

70 RADIĆ 1963d: 67.

71 Arhiv franjevačkog samostana sv. Jeronima, Martinšćica (o. Cres): Spisi A I 4 (1901.), 20. X. 1901.; Arhiv franjevačkog samostana sv. Marije, Glavotok: Spisi 3 (1901. - 1930.), 20. X. 1901. Usp. i RUNJE 2007: 21, 301 i bilj. 678. 
izdanju ispravljena tiskarska greška u naslovu - ... S. Girolamo de' Schiavoni ... - gdje je u talijanskom članu de' apostrof greškom pretvoren u slovo $i$ te otisnut kao dei (... S. Girolamo dei [!] Schiavoni). Knjigu je u svojoj skromnosti Ivančić potpisao samo inicijalima: Studio di F. S. I. I to je, čini se, među ostalim, bio razlog, uz onaj vezan uz jezičnu barijeru, njezina slabijeg poznavanja i citiranja u hrvatskoj historiografiji.

Osvrćući se na to djelo, Ante Liepopili u Listu Dubrovačke biskupije (1902.) iznosi njegov detaljan prikaz te u na početku piše: „Kada se je silna prašina podigla, koja je naslućivala debelu oluju u poslu zavoda sv. Jerka u Rimu; kad neki listovi ustali da poriču sveto pravo, da napadače brane, da uckaju vlasti na očitu nepravdu; u ovo blaženo doba, kada se ne traže tvrdi dokazi i neporecive starinske listine u shraništu gdje im je mjesto, nego se prima kako naj vrijedniji povjesnički dokumenat bulaznjenje ove ili one novine, u namisli da otvori oči nevinim i s neznanjem zavedenim: ustao je m. p. fra S. Ivančić da istinu brani u navedenom djelcu. Osnovom njegovom djelcu jesu učene rasprave na temelju isprava iz rimskih arhivâ blagopokoj. dn. Ivana Crnčića, koji je sve kako marni mrav sabrao i opet sve proveo kroz naj tanje rešeto kritike“. ${ }^{72}$

Unatoč tomu što je brojne izvore i podatke Ivančić u svojoj knjizi preuzeo iz radova Ivana Črnčića ${ }^{73}$, J. Burić u pogledu istraživanja povijesti Zavoda do 1960ih godina ovako konstatira: „O povijesti hrvatske ustanove sv. Jeronima u Rimu pisalo se je dosad već dosta toga. Osobito su za to zaslužni o. Stjepan Ivančić (...), Dr. Ivan Črnčić (...), Dr. Luka Jelić (...) te Dr. Juraj Magjerec (...)“..$^{74}$

Spomenimo i jedan zgodan podatak iz rukopisnih bilježaka popa glagoljaša Zadarske nadbiskupije o. Ante Nižića (1873. - 1963.), kako je Ivančić u studenom 1914. bio u Rimu kod pape Benedikta XV. (1914. - 1922.) te mu je tom zgodom darovao knjigu La questione di S. Girolamo de'Schiavoni in Roma, preporučio Treći red i staroslavenski jezik, na što je papa kimnuo glavom i, pokazao se sklonim prema istomu“". ${ }^{75}$

U Rimu je Ivančić objavio još jedno svoje - danas slabo znano djelo. Naime, riječ je knjizi (brošuri) od svega 50-ak stranica, koju je zajednički napisao s fra

72 LIEPOPILI 1902: 29.

73 Usp. ČRNČIĆ 1868; Isti 1886a: 1-70; Isti 1886b: 1-164; Isti 1886c; Isti 1896: 1-32.

74 BURIĆ 1966: 5. U hrvatskoj verziji svoje knjige Istituto di s. Girolamo degli Illirici (14531953) - Hrvatski zavod sv. Jeronima u Rimu (Collegium S. Hieronymi Illyricorum in Urbe). S dodatkom: Jubilejske proslave (1453-1953) mons. Juraj Magjerec donosi kratku Ivančićevu biografiju i fotografiju (1953b: 45, 143).

75 Arhiv Provincije franjevaca trećoredaca glagoljaša, Zagreb: Lukoranska bilježnica o. Ante Nižića od 1911. do 1920., str. 456., s. v. Benedikt XV. (30. XI. 1914.). Na ovom mjestu zahvaljujem kolegi doc. dr. sc. Ivanu Botici, znanstvenom suradniku u Staroslavenskom institutu u Zagrebu, što me upozorio na ovaj podatak. Upućujem i na njegov rad u ovome časopisu o glagoljici i glagoljaštvu u životu o. Ante Nižića (1873. - 1963.). 
Dinkom Šulinom (Domenico Sulina), a nosi naslov La provincia di Dalmazia ed Istria del Terz' Ordine Regolare di S. Francesco in rapporto alle provincie dello stesso Ordine in Italia (Dalmatinska i istarska provincija Trećega samostanskog reda sv. Franje u odnosu prema provincijama istoga Reda u Italiji). Po svemu sudeći, nastanak knjige bio je potaknut Ivančićevim onemogućivanjem, od strane pojedinaca iz Generalne kurije, u obavljanju privremene dužnosti generala do izbora novog franjevačkog generalnog ministra. Knjiga je tiskana u tipografiji Giorgio Jankovich 1903. te na njezinoj naslovnici stoji još i oznaka Riservato - dakle, za internu uporabu. Tu je knjigu potpisao Ivančić, uz fra Dinka Šulinu, koji je tada (1897. - 1903.) bio definitor reda u Rimu ${ }^{76}$, dakle u isto vrijeme kada je Ivančić bio prokurator Reda.

Ta se knjiga rijetko spominje u literaturi, a gotovo pa nikad i Šulina kao suautor, i usto samo pod naslovom: Terz Ordine Regolare di S. Francesco..$^{77} \mathrm{U}$ njoj se obrađuje vrlo zanimljiva problematika odnosa Hrvatske provincije franjevaca trećoredaca prema talijanskim provincijama istoga Reda, a posebice potonjih prema pitanju Kvarnera, Hrvatskoga primorja i otoka te uopće prava Dalmatinske redodržave. ${ }^{78}$ Fra Antun Badurina u zborniku Franjo među Hrvatima (1976.) piše da je zbog te knjige, a na traženje Kongregacije za redovnike, Ivančića kaznila njegova provincijska uprava moljenjem nekoliko „Očenaša“ ${ }^{79}$ Taj podatak donosi i fra Kerubin Sišul (1892. - 1981.). ${ }^{80}$

Kao krunu svoga dugogodišnjeg, zapravo višedesetljetnog rada, Stjepan M. Ivančić u Zadru 1910. objavljuje iznimno vrijedno i temeljito - svoje životno djelo: Povjestne crte o samostanskom III. Redu sv. O. Franje po Dalmaciji, Kvarneru i Istri i poraba glagolice u istoj redodržavi.

Neke momente i okolnosti nastanka Ivančićeva djela fra Petar Runje ${ }^{81}$ pronalazi u činjenici da se početkom 20. stoljeća glagoljicu napadalo i da su te napade franjevci trećoreci osjetili kao napad na svoju Redodržavu te se sve jačim napadima budila i jačala ,smjelost i ljubav za tu svetinju kao i za zdravu tradiciju namrtu kroz duga stoljeća“. Tako 20. prosinca 1902. provincijal o. Danijel Zec piše do-

76 RUNJE 2007: 338.

77 KAPITANOVIĆ 2006: 210. Usp. i ***Franciscan Resources - Formation (bibliografija), gdje su imena autora potpuno iskrivljena.

78 Usp. RADIĆ 1963d: 67 - „Razočaran i nemalo indigniran, povrati se u Provinciju. Nije čudo, da mu se tada izmakla koja oštrija riječ, te i napisa i objelodani dvije brošure u kojima se opravdava i brani prava Dalmatinske redodržave“. Mislimo da je ovdje došlo do neke zabune jer - koliko je to poznato - postoji samo jedna brošura s takvom tematikom, tj.: La provincia di Dalmazia ed Istria del Terz' Ordine Regolare di S. Francesco in rapporto alle provincie dello stesso Ordine in Italia. 
pis svim samostanima provincije i moli poglavare te sve redovnike da porade na prikupljanju arhivske građe koja bi mogla što bolje osvijetliti prošlost provincije - odnosno - da bi se što prije mogla tiskati „Povijest Provincije“. Želi da se svi materijali koji će biti prikupljeni po samostanima predaju u ruke budućem novoizabranom provincijalu te da se poradi na tiskanju „Povijesti Provincije“ ${ }^{82} \mathrm{Na}$ Redodržavnoj skupštini, koja je održana u Krku od 27. do 29. studenoga 1907., vijećnici i delegati radosno su prihvatili vijest iz pisma oca Stjepana M. Ivančića da je on pri kraju „Povijesti Provincije“ te su svi vijećnici ovlastili oca Povjerenika neka tu Povijest tiska o trošku Provincije. ${ }^{83}$

Knjiga je konačno objavljena 1910. „s dopustom crkovne i redovne vlasti“. Tiskana je u zadarskoj Odlikovanoj Tiskarni E. Vitalianija na ukupno 486 stranica.

Osobito je važno ovdje istaknuti da je to djelo završio i tiskao nakon oporavka od bolesti, koja ga je zahvatila 1906. Isto vrijedi i za izradu Imenika preminulih redovnika svoje Provincije.

Povjestne crte sadrže veliku posvetu: „Slavnoj uspomeni velečastnoga o. Josipa D. ${ }^{\text {ra }}$ Dujmovića, koji sliedeći stope o. Mateja Bošnjaka osnovatelja i o. Antuna Juranića čuvatelja, svojom gorljivošću preporodi u svakom pogledu ovu Starohrvatsku Redodržavu samostanskog III Reda sv. o. Franje prigodom dvadesetpete obljetnice njegove smrti svoje 'Povjestne crte' njegov gojenac smjerno posvećuje“.

Ovdje je pod jednim naslovom Povjestne crte, ali u dvjema knjigama (zajedno tiskanima) Stjepan M. Ivančić prikupio i priopćio sljedeće.

U „Prvoj knjizi“, koja obuhvaća 255 stranica teksta, nalazi se povijest Reda s kratkim općim uvodom, zatim je drugi dio posvećen glagoljici, treći dio životopisima istaknutih pojedinaca, a četvrti opisima samostana i crkava.

„Druga knjiga“, na 231 stranici, nosi naslov: Prilozi odnoseći se na povjest $i$ na staro-slavensko bogoslužje 00. Samostanskog III. Reda S. O. Franje u Dalmaciji, Kvarneru i Istri a to Izprave, Pečatnice, Ostavštine, Namještaji, Povlastice, Dokaznice, Pohvalnice, Naredbe i razni primjerci izdani, prevedeni ili prepisani, kojih u većem dielu sabrali 18. vieka Mnogoč. O. Dragutin Radić i Preč. O. Antun Juranić, te se nalaze u redodržavnom Arkivu, ili u Arkivu pojedinih obstojećih Samostana ujedno ih sakupio i za tisak priredio O. S. I. (Iz bergamina i starih pamučnih karata).

Tako se zapravo iza skromnog naslova krije velika knjiga iznimnog značenja, koja govori o Trećem samostanskom redu sv. o. Franje na hrvatskim prostorima - od samog osnutka samostanskog Trećeg reda pa do širenja i utjecaja na druga područja.

Arhiv franjevačkog samostana sv. Jeronima, Martinšćica (o. Cres): Spisi A I 4 (1902.), 20. XII. 1902.

83 Arhiv franjevačkog samostana sv. Jeronima, Martinšćica (o. Cres): Spisi A I 4 (1907.), 4. XII. 1907. 
To je Ivančićevo historiografsko djelo usporedivo sa sličnim nastojanjima kao što su Storia dei frati minori dai primordi della loro istituzione in Dalmazia e Bossina fino ai giorni nostri (1863. - 1864.) fra Donata Fabijanića, Djelovanje franjevaca u Bosni i Hercegovini za prvih šest viekova njihova boravka (1881. - 1887.) fra Mije Vjenceslava Batinića ili, pak, s djelom fra Stipana Zlatovića Franovci države Presvet. Odkupitelja i hrvatski puk u Dalmaciji (1888.). ${ }^{84}$

Zabilježeno je svega nekoliko osvrta na ovo Ivančićevo glavno djelo. Ivan Milčetić, pod naslovom „Franjevci i glagolica“, napisao je kraći osvrt u mjesečniku Družtva hrvatskih književnika - Suvremenik. ${ }^{85}$ Ukratko je prepričao osnovne momente iz knjige, spomenuvši učenost i marljivost o. Stjepana M. Ivančića. Također se očitovao o samom hrvatskom jeziku kojim je djelo napisano, a koji je prema Milčetiću - ,prilično dobar“. Nadodaje još neke podatke o jednom Klimantovićevu kodeksu koji se čuva u Zagrebu, a za koji Ivančić nije znao. Unatoč tomu, Milčetić s pravom ističe da „knjiga donosi znatnih podataka, važnih za istoriju hrvatske prosvjete i hrvatske književnosti, a naročito za istoriju hrvatskoga glagolizma“ - stoga nijedan - „samostanski red po hrvatskim zemljama ne može se iskazati ljepšim djelom od ovoga“. Napominje da je povećom svotom tisak poduprla i Jugoslavenska akademija znanosti i umjetnosti. ${ }^{86}$

Sličan prikaz objavljen je i u Narodnoj prosvjeti - mjesečniku za školstvo, prosvjetu i književnost koji je izlazio u Pazinu, ali bez naznake autora. „Već samo površno naše suho kazalo nam kaže jasno, da je djelo svakako zanimivo. Sadržaj je uz to nanizan lakim i razumljivim stilom bez teške naučnjačke ukočenosti, koja nestrukovnjaka sili, da ojađen baci knjigu iz ruke prije nego li je dočita“. Na kraju se teksta apelira kako bi svaki samostan, ali i redovnik, svećenik ili svjetovnjak trebao nabaviti primjerak rečene knjige. Ujedno se poziva: „Dao Bog, e bi se na njega ugledao i koji franjevac, benediktinac, svećenik mirski itd., pa nam prikazao historiju svoga reda u našim stranama, respektive naše koje biskupije bilo sadašnje bilo negdašnje!“"87

S druge, pak, strane, dvije godine potom dr. Ante Vukić iz Dubrovnika vrlo se kritički osvrće na Ivančićevu knjigu. Kritiku je objavio u novinama Prava Crvena Hrvatska ${ }^{88}$ Štošta zamjera autoru - od jezika preko povijesnih činjenica do interpretacija. Iako ističe važnost knjige ne samo ,za povijest naše literature nego i kulture", upozorava da se zapravo na njezin sadržaj nitko nije osvrnuo izuzev Ivančićeva prijatelja Milčetića. Stoga je on odlučio podrobnije prikazati njezin

\footnotetext{
${ }^{84}$ Usp. i historiografski pregled u KAPITANOVIĆ 2006: 205-211; IRIARTE 2013: 495-505, 537-547. 
sadržaj. Povjestne su crte - tvrdi Vukić - ,primitivno napisane“. Opravdava takav svoj stav ovim riječima: „Najslabija je njihova strana metoda. Tražiš li u njima marljivosti i savjesti, naći ćeš je na pretek; tražiš li naprotiv u njima moderne historijske metode, duboke analise, otmene sintese, kompozicije, strukture i stila u širem smislu riječi, te individualnog shvaćanja i risanja milleu-a u Taineovu (H. Taine, op. a.) smislu, i osobitog smisla za sistem, ne ćeš naći u obilju. Prikazivanje i obragjivanje predmeta sa svojom primitivnošću posjeća nas na knjigu 'Zara cristiana' od Bianchi-a“. Potom se oštrica usmjerava na jezik knjige, koji je po Vukićevu sudu „loš“, odnosno „slab“, unatoč tomu što je više pojedinaca bilo na ruku Ivančiću u pripremi djela za objavu. No, ovdje valja primijetiti da se jezična kritika tiče i Milčetića, koji je o istoj stvari napisao suprotno mišljenje. U nastavku su iznesena neka drugačija tumačenja postanka trećoredaca u Dalmaciji. Prema Vukiću, trećoreci su u Zadru „od vajkada“, a kasnije im se usred osmanskoturske najezde pridružuju trećoreci iz Bosne: „Budući da je veliki broj iz Bosne nadošao, malen red trećoredaca iznova procvjeta, te je sada sasvim izgledao kao bosanski red. Eto tako zamišljam povijest trećoredaca u Dalmaciji“. Nadalje, kritičar zamjera Ivančiću to što nije osobno, kad već ondje boravi, konzultirao neka povijesna vrela u Zadru. Iznosi pohvalu autoru za drugo poglavlje koje se odnosi na glagoljicu i staroslavensko bogoslužje zbog obilja novih podataka koje donosi. Također ga pohvaljuje zbog ispravne konstatacije „kako mletačka vlada nije nikada proganjala trećoredaca“". No, u pogledu protestantizma, napose u Istri, zamjera mu neupućenost u suvremenu literaturu, slavističku i historiografsku. U pogledu Priloga izražava zadovoljstvo množinom objavljenih isprava i drugih spisa (Klimantović, Galić i dr.), ali ukazuje ne nedostatak hrvatskih regesta uz svaki dokument. Međutim, na koncu Vukić ipak rezimira pozitivno: „Ivančićeva je knjiga uza sve nedostatke važna, te je zaslužio, da se netko na nju osvrne stvarnim referatom. Trećoreci se mogu ponositi ovom knjigom, jer su u njoj dobili ono, što nema nijedan red u Dalmaciji, a mi moramo biti piscu zahvalni, što nam je toliku gragju iznio za povijest naše kulture i literature“".

U brošuri Pobjeda glagolice kroz tisućljetnu borbu don Frano Ivanišević (1863. - 1947.) ubraja Ivančića među istaknute borce za glagoljicu, a njegovo djelo ovako ocjenjuje: „Iz starinskih povelja, pergamena, ugovora, pečatnica, ostavština pobrani su autentični dokazi o porabi glagolice uzduž čitave obale Jadrana kroz sve vijekove. I danas su franjevci trećoredci najbolji čuvari glagolice. U crkvi sv. Mihovila u otudjenom Zadru i danas se čuje u misi Ćirilova besjeda““ 89

Puno kasnije kritički se prema ovome djelu izrazio Vjekoslav Štefanić u radu „Glagoljaši u Kopru“, objavljenom $1956 .{ }^{90}$ Doduše, to treba gledati kroz prizmu koparskih trećoredaca, a koje je spletom okolnosti Ivančić tek površno obradio jer

\footnotetext{
IVANIŠEVIĆ 1930: 48-49.

90 ŠTEFANIĆ 1956: 203-329 + 7 tab.
} 
je taj samostan bio ukinut, a građa razasuta i teško dostupna. ${ }^{91}$ Štefanić piše da će se u svojoj studiji nadovezati na dosadašnju literaturu o tom predmetu - glagoljašima u Kopru, a osobito na „gotovo jedinu knjigu kod nas, koja - makar i nedovoljno kritično - prikazuje povijest i objelodanjuje izvore za povijest te dalmatinskoistarske trećoredske provincije, a to je knjiga Stjepana Ivančića: Povjestne crte

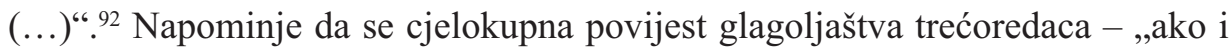
nedovoljno pregledno i manje kritično" - može naći u Ivančićevu djelu, napose u drugom dijelu pod naslovom Glagolica (str. 114-162), zajedno s Prilozima B pod naslovom O staroslovenštini (str. 164-210). ${ }^{93}$ No, glavno mjesto kritici Štefanić pronalazi u drugom dijelu citirane knjige pod naslovom „Prilozi“ (koji obuhvaća 229 stranica), gdje je Ivančić ,publicirao mnogo dokumenata, koji se tiču povijesti franjevaca samostanskog III. reda u našim krajevima. Šteta je što ti dokumenti nisu kritičnije izdani: uzeti su često iz nepouzdanih prijepisa, nije označen izvor, odakle su preuzeti, ma da je to ponajviše arhiv provincije ili kojega samostana, $\mathrm{i}$ usto je katkada nepouzdano čitanje. On nije imao prilike poslužiti se građom iz koparskog arhiva, pa ću ga na više mjesta moći ispraviti i dopuniti““ ${ }^{94}$ Prema našem sudu, ova kritika tek djelomično stoji jer je vrijeme pokazalo da su publicirani izvori kod Ivančića itekako korisni, ali ujedno podložni kritičkom promišljanju i provjeri te paleografskim i jezičnim opservacijama jer je svaki istraživač uvijek upućen na izvornu građu, ako to od njega zahtijeva dotično istraživanje. Egdotički je to urađeno u skladu s vremenom i uvjetima djelovanja samoga Ivančića, a prigovor o nenavođenju mjesta podrijetla pojedinog izvora zapravo ne stoji jer na naslovnoj stranici „Priloga“ jasno piše da se isprave i drugi spisi: „nalaze u redodržavnom Arkivu, ili u Arkivu pojedinih obstojećih Samostana“.

U pogledu vjerodostojnosti isprava koje su objavljene u „Prilozima“, ovdje nema mjesta sumnji; dovoljno je konzultirati Arhiv Provincije franjevaca trećoredaca - Regesti pergamena ${ }^{95}$, tj. usporediti taj analitički inventar s objavljenim ispravama i vidjeti da se Ivančić itekako rukovodio historiografskim postulatima.

91 O tome pitanju Vj. Štefanić kaže: „U arhivu provincije redovničkih franjevaca trećoredaca u Zagrebu (samostan sv. Ksavera) nalazi se vrlo malo materijala, koji je na bilo koji način potekao iz koparskog samostana ili se tiče tog samostana. Kako je taj arhiv u slabom redu, ovaj je materijal ondje raštrkan i bez posebnih oznaka; a možda će se ondje naći i još koji izvor za koparski samostan. O. Stjepan Ivančić se ovim materijalom poslužio, ali nedovoljno, a nije to često ni rekao" (ŠTEFANIĆ 1956: 241).

ŠTEFANIĆ 1956: 205.

Isto: 211

Isto: 322 , bilj. 3.

Petar Runje (ur.). Zagreb: Provincijalat franjevaca trećoredaca, 1980. - umnoženo kao prilog Vjesnika franjevaca trećoredaca glagoljaša, br. 3-4 i 5-6 (1979) i 1-2 (1980). Usp. i rad Mirjane Matijević Sokol Zbirka isprava u Arhivu Provincije franjevaca trećoredaca glagoljaša u ovome časopisu. 
Iste godine - 1910. - kao odgovor na potrebu i traženja unutar svoje redovničke zajednice, Ivančić sastavlja i ciklostilom daje umnožiti Imenik preminulih redovnika samostanskog III. reda S.O.F. redodržave s. Jerolima u Dalmaciji, Kvarneru i Istri (1910.). ${ }^{96}$ Sam u Predgovoru, pak, ističe: „Ima nekoliko godina e se je i kod nas uveo vrlo liepi običaj, da se za sutrašnji dan čitaju pri stolu godovi mrtvih Redovnika. (...) Nego stara je knjižica, gdje se čitali godovi, bila nepodpuna. U njoj, uz neznatne iznimke, spominjali se samo mrtvi Redovnici, počam od druge polovice osamnaestoga stoljeća: jer pomni sastavljač nije imao pri ruci ako ne jedino mrtvačku knjižicu (Vacchetta) glavotočkog Samostana i po koji komad knjižice Zaglave i Školjića, a falilo mu, kô što i danas fale predjašnje tih i drugih samostana. Stoga, uza svu dobru nakanu, djelo nije moglo izaći savršeno. Eda se doskoči toj manjkavosti, te se po mogućnosti sa spominjanjem preminulih dopre do one dobe, kad se naši Redovnici pojavili u Dalmaciji, pobrinuo se podpisani eda zaboravi otme i one koji bi inače uviek u zaboravi ostali. Osim jur spomenutih mrtvačkih knjižica il razderanih komada, pretresao je i uztrpljivo pregledao razne druge knjige i knjižice, osobito stare debele Dnevnike sve glagolicom napisane po najstarijim samostanima Školjića, Martinšćice, Glavotoka i Dubašnice, te je po njima paljetkujuć, dopro do broja 473 nebilježenih mrtvih Redovnika. Od ovih je 239 kojih je naznačen dan, mjesec ili godina njihova preminuća, a 234, kojih se bilježi samo dan, mjesec, godina njihova zadnjeg spomenka. Tako kad se ovaj broj pridoda broju 299 stare knjižice, ima se ukupno u sve broj 772: naime 538 Redovnika preminulih, označenih sa križićem $\uparrow$, a 234, kojih se još za života zadnji put spominje, označenih sa zviezdicom *. Cienim ovdje spomenuti, da navlastito u Kazalu nalazi se točno naznačena godina, mjesec i dan preminuća redovnika, dočim je u samoj knjizi više puta promjenjen dan, pa čak i mjesec zbog tehničkih il drugih kojekakvih uzroka“" ${ }^{97} \mathrm{U}$ nastavku Ivančić apelira da bi ovakvo djelo morao imati svaki trećoredski samostan te daje uputu kako ga i kada čitati. Na koncu kaže da je Imenik, tj. ovo djelo: ,namienjeno našim milim pokojnicima, a sastavljeno jedino na uhar naše učeće se redovske mladeži, pa ga ja dobrovoljno predajem u ruke M.P.O. ${ }^{98}$ Redodržavnika, neka ga on po svojoj uviđavnosti porazdjeli po našim samostanima, polag vriednosti udari dotičnu cienu te ju utjera na korist rečene mladeži “. ${ }^{99}$ Imenik je, prema pisanju fra Ignacija Radića, nastao na temelju godovnika, koji je koncem 19. stoljeća izradio provincijal o. JacintoCarevko Bu(j)ić (1837. - 1918.). ${ }^{100}$

\footnotetext{
96 Drugo izdanje toga Imenika priredio je fra Petar Runje, a objavljeno je 1987.

97 Imenik preminulih redovnika 1910: Nekoliko rieči predgovora (bez paginacije). Taj je Ivančićev Predgovor ponovljen i u drugom proširenom izdanju Imenika iz 1987.

98 Napomena: M. P. O. = mnogo poštovani otac.

99 Imenik preminulih redovnika 1910: Nekoliko rieči predgovora (bez paginacije).

100 RADIĆ 1963e: 93.
} 
Pola stoljeća kasnije (1965.), u ocjeni važnosti toga Imenika, fra Šime Vladović ističe da trećoredska franjevačka Provincija mora biti iskreno zahvalna velezaslužnom ocu Ivančiću, kako za ovo djelo, tako i za sav njegov preostali neumoran rad: „Tu njegovu marljivost i vanrednu ljubav prema učećoj mladeži i provinciji moramo tim više cijeniti, ostati mu istinski i trajno zahvalni““ ${ }^{101}$ No, napominje da ovaj Ivančićev „Imenik, kao i svako ljudsko djelo, nije potpun ni savršen“, a razlog tomu leži u činjenici što su knjige pokojnika kod trećoredaca za starija doba nestale, a usto bili su „veoma rijetki, koji su znali cijeniti vrijednost starine, pogotovo vanrednu vrijednost glagoljice uopće, a za našu provinciju napose“. ${ }^{102}$ S druge, pak, strane određene skupine arhivskih izvora Ivančiću nisu bile poznate ili dostupne. Stoga autor poziva na izradu - kako zbog novih pokojnika, tako i u međuvremenu novopronađenih podataka (i sam ih dijelom bilježi u svome tekstu) - drugog dopunjenog izdanja Imenika, a što će se realizirati tek dvadesetak godina kasnije.

Zadnje, pak, za života tiskano Ivančićevo djelo jest knjižica pod naslovom $N e$ što o hrvatsko-glagolskim piscima samostanskih Trećoredaca. Tiskana je u Zadru 1911., a temelji se - isto kao što je to bio slučaj i s njegovim prvim objavljenim djelom Poraba glagolice (1887.) - na prije toga publiciranim novinskim člancima. Riječ je, dakle, o sabranim člancima, koji su pod istoimenim naslovom „Nešto o hrvatsko-glagolskim piscima samostanskih Trećoredaca“ izlazili u nizu tijekom studenog i prosinca 1911. u Hrvatskoj kruni-glavnom glasilu Stranke prava u Dalmaciji, koje je bilo pod uredništvom vrlo utjecajnog i politički angažiranog don Ive Prodana. U knjižici Nešto o hrvatsko-glagolskim piscima donosi životopise trećoredskih autora koji su djelovali u razdoblju od 15. do 19. stoljeća, pa tako sadrži iscrpnije podatke o fra Petru Milutiniću, fra Šimunu Klimantoviću i fra Mateju Zadraninu te polemizira s pojedinim navodima Rudolfa Strohala (1856. - 1936). Tim je radom Ivančić ispravio pojedine Strohalove tvrdnje iznesene u Prosvjeti (br. 11.). Bilo je to zadnje Ivančićevo djelo koje je za njegova života ugledalo tiskarske strojeve i svjetlo dana.

\section{III.}

Ivančiću su i posmrtno tiskom objavljeni još neki radovi. Tako je gotovo u literaturi nepoznata zbirka dokumenata o crkvi i samostanu sv. Ivana Krstitelja u predgrađu Zadra i o glagoljaštvu, objavljena u Rimu 1950. s odobrenjem crkvenih vlasti. Kao autori navedeni su Parčić, Ivančić i Zec, a knjiga nosi naslov: Documenti della Chiesa e del Convento di S. Giov. Battista nel Borgo di Zara e

$\overline{101}$ Usp. VLADOVIĆ 1965: 41.

$102 \mathrm{Na}$ istome mjestu. 
del Glagolito. No, zaustavimo se na autorskom trojcu i njihovoj suradnji. Naime, još je D. A. Parčić iskazivao interes za pisanu riječ koja bi osvijetlila povijest franjevaca trećoredaca i glagoljice, a taj je posao marljivo nastavio Ivančić, dok je o. fra Danijel Zec (1845. - 1935. $)^{103}$ za vrijeme svoga boravka u Rimu (1903. - 1912.) u svojstvu prokuratora - „obskrbnika u redovrhovnoj kuriji“ - također istraživao $i$ ispisivao isprave iz Tajnog vatikanskog arhiva ${ }^{104} \mathrm{i}$ dr., a koje se odnose na trećorece i glagoljicu. Tako je nastala ova zbirka važnih dokumenata, sada zasebno tiskana nakon smrti sve trojice autora, a zapravo preuzeta u cijelosti, uz drugačiji redoslijed i nekoliko jezičnih sitnica, iz Ivančićevih Povjestnih crta. Na 53 stranice priređeni su tako dokumenti na talijanskom, latinskom i hrvatskom jeziku, sukladno egdotičkim načelima. Na početku se nalazi dokument o crkvi i samostanu sv. Ivana Krstitelja ${ }^{105}$ - a) Documenti della Chiesa e del Convento di S. Giovanni Battista nel Borgo di Zara e del Glagolito Querina De Ferantea (str. 3-7). ${ }^{106}$ Drugi dio, od 9. do 53. stranice, obuhvaćaju - b) Dokumenti o staroslovenstini (glagolici). ${ }^{107}$ Iako se radi o ponovljenom izdanju već poznatih dokumenata, ono još jedanput ukazuje na iznimnu važnost starih listina i drugih spisa o začecima i djelovanju franjevaca trećoredaca na hrvatskim povijesnim prostorima.

Zbog šire nedostupnosti te potrebe izrade revidiranog i nadopunjenog Nekrologija franjevaca trećoredaca, uslijed, pak, dugogodišnjih traženja u tome pravcu ${ }^{108}$ i višegodišnjeg rada, 1987. objavljeno je drugo prošireno izdanje Imenika preminulih redovnika Hrvatske provincije franjevaca trećoredaca, koje je priredio o. fra Petar Runje. Kao temelj poslužio je, dakako, Ivančićev Imenik. U Predgovoru Runje ističe: „Budući da u nekim našim kućama više ne postoji Imenik preminulih redovnika, koji je pripremio i objelodanio u Zadru 1910. pok. o. Stjepan Ivančić, odlučili smo ponovno ga umnožiti. Kroz minulih sedamdeset godina umrlo je sedamdesetak redovnika, koje smo u ovom izdanju unijeli u ovaj nekrologij. (...) Imena redovnika unesena u ovaj nekrologij iz 14. i 15. stoljeća pronašao sam u dokumentima kod zadarskih javnih bilježnika u Historijskom arhivu u Zadru. Dio podataka za kasnije razdoblje pronađen je u objavljenim dokumentima i raznim edicijama. (...) Ovaj donekle obnovljen i popunjen Imenik preminulih redovnika bio je pripremljen u 800. godišnjici rođenja sv. oca Franje“. ${ }^{109}$

\footnotetext{
103 RUNJE 2007: 330-331.

104 IVANČIĆ 1910: IV.

105 Za nove spoznaje o ovoj crkvi vidi Iskoni bê slovo. Zbornik radova o glagoljici i glagoljašima zadarskog kraja i crkvi Svetog Ivana Krstitelja 2001.

106 Usp. IVANČIĆ 1910, Prilog C, 211-215.

107 Usp. Isto, Prilog B, 163-210.

108 Usp. VLADOVIĆ 1965: 41-45.

109 Imenik preminulih redovnika Hrvatske provincije franjevaca trećoredaca 1987: Predgovor drugom izdanju (bez paginacije).
} 
$I V$.

U odnosu na tiskana djela manje su poznati i obrađeni Ivančićevi rukopisi i ostali spisi koji se čuvaju u Arhivu Provincije franjevaca trećoredaca u Zagrebu i drugdje, a to je zapravo po svim onim samostanima gdje je on boravio ili službovao (Zadar, Krk, Glavotok, Školjić) te u Rimu (Generalna kurija, Sv. Kuzma i Damjan). No, već sada možemo kazati da su ti materijali mahom rukopisi ili nacrti njegovih objavljenih djela te različiti ispisi, kako iz arhiva, tako i iz tiskane građe, kao što je to, primjerice, Bullarium Franciscanum. U Arhivu Provincije u Zagrebu čuva se arhivska kutija s oznakom: Građa i rukopisi za povijest Reda $i$ Provincije (Ivančić $i$ Zec). To su zapravo radni materijali za spomenutu povijest, koju su - svatko u svoje vrijeme - ispisivali i priređivali Ivančić i o. fra Danijel Zec.

U Arhivu Generalne kurije Trećeg samostanskog reda sv. Franje u Rimu (Archivio della Curia Generalizia TOR / Archivio generale del Terz' Ordine Regolare di S. Francesco, Roma) čuva se Ivančićev rukopis pod naslovom: Cronologium seu Historica monumenta Tertii Regularis Ordinis de Poenitentia Sancti Patris Francisci e variis fontibus a p. magistro Stephano M. Ivancic T. O. R. olim procuratore generali eiusdem Ordinis collecta et ordinata superiorum permissu.

Riječ je o povijesti cijeloga Trećega reda sv. Franje, koju je Ivančić napisao na latinskom jeziku na temelju brojnih vrela i literature, koje je skupio i obradio kako za svoga boravka u vječnome Gradu ${ }^{110}$, tako i za vrijeme redovničkog života provedenog u Zadru i na Školjiću. Završio ga je - unatoč bolesti i starosti ${ }^{111}-\mathrm{u}$ Zadru, ali je ostalo u rukopisu. ${ }^{12}$ To je djelo 1957. priredio i kao rukopis ciklostilom umnožio fra Raffaele Pazzelli (1922. - 2011.). Sastoji se od dviju knjiga, a svaka od njih od dvaju dijelova (Liber I. Pars I et II.; Liber II. Pars I et II). Zbog važnosti to je djelo Pazzelli - inače jedan od vodećih povjesničara trećoredskog franjevaštva te autor knjige Il Terz'ordine regolare di s. Francesco attraverso $i$ secoli (1958.) - priredio te u impressumu naveo sljedeće podatke: Editio Assisiensis, cura R. P. Raphaelis Pazzelli, anno 1957 exarata.

Ivančićevo djelo Cronologium nakon Proemija sadrži dvije velike cjeline, od kojih je svaka raspoređena u dvama dijelovima: I. 1. De Tertio regulari ordine S. P. Francisci in genere; I. 2. De congregationibus Tertii ordinis in variis Europae partibus; II. 1. De Tertio regulari ordine specialiter in Italica congregatione

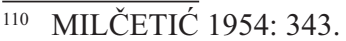

111 LUCONI 1935: 283.

112 „Kroz to vrijeme (poslije Prvog svjetskog rata - op. a.) dobio je na posudbu neki stari pisaći stroj i počeo jednim prstom otipkavati, mislim, dokumente povijesti našega Reda. To se njegovo zadnje djelo negdje zamelo u Svetom Kuzmi u Rimu, (tako sam čuo) da nekom posluži za tiskanje povijesti našega reda. Taj original morao bi se naći u provincijalnom arhivu“" (RADIĆ 1963d: 69). 
designato; II. 2. De unionibus variarum congregationum seu provinciarum tertio regulari ordini Italicae congregationis. U prilogu C. nalaze se Documenta varia Tertium ordinem regularem S. Francisci de Poenitentia concernentia.

U našoj se literaturi ta djela određuju kao Povijest Reda i Zbirka povijesnih spomenika Tré́ega Reda. ${ }^{113}$ Inače je sam naslov - Cronologium - zapravo uzet prema glasovitoj knjizi fra Francesca Bordonija - cjelokupnoj povijesti Trećega samostanskog i svjetovnog reda sv. Franje - Historia Tertii Ordinis S. Francisci. Cronologium fratrum, et sororum tam regularis quam secularis, objavljenoj u Parmi 1658. ${ }^{114}$

No, kakva je zapravo vrijednost toga Ivančićeva velikoga djela možda je najbolje ocijenio fra Raniero (Raynerius) Luconi u knjizi Il Terzo Ordine Regolare di S. Francesco (1935.): „L'autore ha consultato tutte le fonti antiche e moderne e gli autori più accreditati, specialmente l'Archivum Franciscanum Historicum di Quaracchi; ed ha scritto una storia generale, particolareggiata, documentata e discussa - anche troppo - più di quella del Bordoni - di tutte le Congregazioni Terziarie. Alla Congregazione Italiana consacra tutto il libro II.“"115

Dakle, Luconi uspoređuje rukopisno Ivančićevo djelo s djelom još jednoga trećoreca - fra Francesca Bordonija - uglednog talijanskog pisca i povjesničara, autora brojnih djela koja su tiskom objavljena, ali i onih u rukopisu. Bordoni je, primjerice, 1666. sastavio popis svih svetih i blaženih franjevaca trećoredaca i trećoredica: Sacrum Sillabarium de vitis Sanctorum, Beatorum et Servorum Dei Tertii Ordinis S. Francisci tam Secularis, quam Regularis stilo puro... (...). Taj se rukopis također čuva u Arhivu Generalne kurije Trećeg samostanskog reda sv. Franje u Rimu.

Međutim, Luconi nastavlja dalje: „Il forte studio storico-critico-giuridico ha pregi indiscutibili. Ma più che una storia vera e propria è, come dice il titolo Historica Monumenta una copiosa raccolta ordinata di documenti. La si può chiamare storia; ma i documenti la rendono troppo pesante. Tuttavia rimane sempre una ricchissima miniera, dove uno studioso può attingere le notizie che vuole, sia per la storia nostra, che per la storia delle Congregazioni estere dei Paesi Bassi, della Germania, Francia, Spagna, Portogallo e Irlanda. Il suo principale maestro, per la storia antica, è sempre il nostro illustre P. Bordoni. “116

113 BADURINA 1976: 232.

114 BORDONUS 1658. Riproduzione anastatica - a cura di Lino Temperini (Roma: Franciscanum, ${ }^{2} 1998$.).

115 LUCONI 1935: 283, bilj. 1. (,Autor je konzultirao sve stare i suvremene izvore te najvjerodostojnije autore, posebno Archivum Franciscanum Historicum u Quaracchiju; i napisao je povijest svih trećoredskih kongregacija koja je opća, podrobna, dokumentirana i u kojoj je rasprava, čak i pretjertano, opširnija od Bordonijeve. Talijanskoj Kongregaciji posvećuje cijelu II. knjigu.")

116 LUCONI 1935: 283, bilj 1. („Ova temeljita povijesno-kritičko-pravna studija ima neospornu vrijednost. Ali ona je, kao što kaže i sam naslov Historica Monumenta, više obilna zbirka sređenih isprava, negoli prava povijest. Ona se može nazvati poviješću, ali je dokumenti previše opterećuju. Bez obzira na to, njegova je povijest i dalje izuzetno bogat rudnik, odakle svaki istraživač može crpsti podatke koje hoće, kako za našu povijest, tako i za povijest inozemnih Kongregacija Nizozemske, Njemačke, Francuske, Španjolske, Portugala i Irske. Njegov (Ivančićev - op. a.) je glavni učitelj, za staru povijest, uvijek naš slavni o. Bordoni.“) 


\section{Umjesto zaključka}

Unatoč svemu prije izrečenomu iz života i rada jednoga zaslužnog franjevca i povjesničara, nažalost, još nema jedne zaokružene studije - usuđujemo pogled usmjeriti i k nečemu većem od toga: doktorskom radu o životu i djelu o. fra Stjepana M. Ivančića - iako on takvo što svakako zaslužuje, i to ne samo kao redovnik-svećenik, već i kao historiograf. Igrom sudbine, puno je bolje prošao glasoviti glagoljski kodeks Ivančićev zbornik iz 14./15. stoljeća. ${ }^{117}$ Nazvan je upravo tako po Ivančiću, koji ga je pronašao u samostanu franjevaca trećoredaca na Glavotoku. Takvo mu je ime s pravom pridjenuo Ivan Milčetić118, a danas se čuva kao jedna od najvećih vrijednosti u Arhivu Provincije franjevaca trećoredaca glagoljaša na Ksaveru u Zagrebu. „Ovaj je zbornik“ - piše Milčetić 1890. - „religiozno-moralne sadržine, a zovem ga Ivančićevim, jer ga je našao i prvi u javnosti spomenuo učeni i rodoḷubni otac Stjepan Ivančić, sada definitor frańevaca u Rimu““. ${ }^{119}$ Prema Ivanki Petrović, autorici iznimno vrijednog biobibliografskog članka o Ivančiću u Hrvatskom biografskom leksikonu, on je, naime, desetljećima tragao „za glagoljskim spomenicima u Istri i Dalmaciji, a najvrjedniji rukopis koji je našao - za hrvatsku književnu kulturu iznimno važan glagoljski zbornik iz XIV/XV. st. - Milčetić je po njem nazvao Ivančićevim zbornikom (... “. ${ }^{120} \mathrm{~S}$ druge, pak, strane Stjepan Antoljak u svom opsežnom djelu Hrvatska historiografija na nekoliko mjesta citira dva Ivančićeva djela, ali njega, začudo, ne ubraja niti obrađuje unutar pripadajućih poglavlja te ga time zapravo ne uvrštava u našu historiografiju. ${ }^{121}$

U inače vrlo skromnom članku Vladimir Marković ocjenjuje da je Ivančićev rad bio „znanstvenog a u isto vrijeme nacionalnog značenja“. ${ }^{122}$ Fra Petar Runje

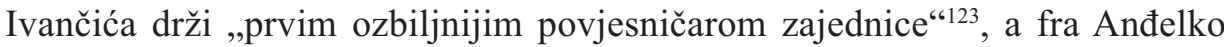
Badurina svojevremeno je (1992.) dao poticaj da se 2002. znanstvenim skupom obilježi 150. obljetnica Ivančićeva rođenja te 100. godišnjica Parčićeve smrti. ${ }^{124}$

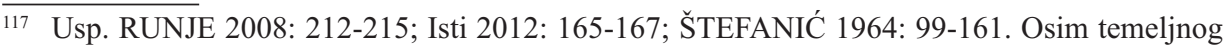
rada Ivanke Petrović (Bogorodičina čudesa u Ivančićevu zborniku, hrvatskoglagoljskom spomeniku 14./15. st., 1972), o Ivančićevu zborniku napisana je i doktorska disertacija - Ivan Kosić, Ivančićev zbornik: hrvatskoglagoljski neliturgijski rukopis iz XIV./XV. st., mentor akademik Eduard Hercigonja, Zagreb: Filozofski fakultet Sveučilišta u Zagrebu, 2010. Usp. BOTICA I GALOVIĆ 2012: 243, bilj. 2.

118 MILČETIĆ 1890: 40-79.

119 Isto: 40. Usp. i MILČETIĆ 1911: 256-258; STROHAL 1915: 160-161.

120 PETROVIĆ 2005: 126.

121 ANTOLJAK 1992: 48-50; Isti 2004: 46-48.

122 MARKOVIĆ 1975: 379.

123 RUNJE 1985: 108.

124 BADURINA 1993a: 164; Isti 1993b: 164; Isti 1993c: 164. 
Nažalost, do toga nije došlo. No, fra A. Badurina je u osnovnim crtama sažeo neke misli i činjenice o Ivančiću, smatrajući da on, imajući pritom na umu spomenutu Parčićevu posvetu mladomisniku, nije iznevjerio Parčića, koji je, pak, dobro prepoznao njegove sposobnosti: ,no prilike nisu dopustile“ - piše Badurina - ,da obilnije odjelotvori svoju ljubav prema materinskom jeziku i iskru pjesničkoga duha“. Stoga je svoju darovitost ,morao dokazivati na političkom i povjesničkom području boreći se za jačanje nacionalnog identiteta naših ljudi i za opstanak staroslavenskog jezika u bogoslužju koje je upravo u to doba bilo ugroženo". ${ }^{125}$

Konstatirajmo i to da je Ivančić kao povjesničar bolje cijenjen od strane talijanskog franjevca Ranierija Luconija nego od pojedinih hrvatskih autora. Poprilično točnu ocjenu Ivančićeva života i djela dao je njegov subrat fra Šime Vladović, koji je u nekoliko rečenica skicirao sljedeće: „Dok je bio zdrav, obnašao je razne važne službe u provinciji i u redu, kroz koje se nije mogao više posvetiti tim korisnim zanimanjem (tj. istraživanju i pisanju - op. a.). Kasnije, dva puta udaren od kapi (dok treći put potpuno klonuo) nije imao snage za višestruki posao oko naumljenih djela. Kao takav pogotovo nije se mogao posvetiti istraživanju po državnim arhivima“. ${ }^{126}$ Fra Nikola Milčetić (1891. - 1970.) u članku objavljenom 1954. u Analecta Tertii Ordinis Regularis Sancti Francisci zapisao je ovako: „Inter religiosos Tertii Ordinis Reg. S. Francisci recentioris aetatis scientia, operositate atque religiosa observantia P. Stephanus Maria Ivancic, alumnus Provinciae S. Hieronymi in Croatia, valde excelluit. Ob praeclaras eius dotes procul dubio memoria dignus est“". ${ }^{127}$

Najzad, slobodni smo konstatirati da je historiografsko djelo fra Stjepana M. Ivančića i danas poticajno, iako je od njegove objave prošlo više od jednog stoljeća. ${ }^{128}$ Ono je i nadalje temelj za bilo koja istraživanja povijesti Trećega samostanskoga reda sv. o. Franje od pokore na hrvatskim povijesnim prostorima.

125 Isti 1993a: 164; Isti 1993b: 164; Isti 1993c: 164.

126 VLADOVIĆ 1965: 41.

127 MILČETIĆ 1954: 341 („Među redovnicima Trećega samostanskog reda sv. Franje u moderno doba znanjem, marnošću i savjesnim izvršavanjem redovničke dužnosti veoma se odlikovao o. Stjepan Marija Ivančić, gojenac Provincije sv. Jeronima u Hrvatskoj. Zbog svojih izvanrednih vrlina bez sumnje je dostojan uspomene.").

128 Njegovu je misiju u naše dane na sebe preuzeo njegov subrat mr. sc. fra Petar Runje (1938. 2014.). Usp. BOTICA I GALOVIĆ 2012: 243. 


\section{Slikovni prilozi}

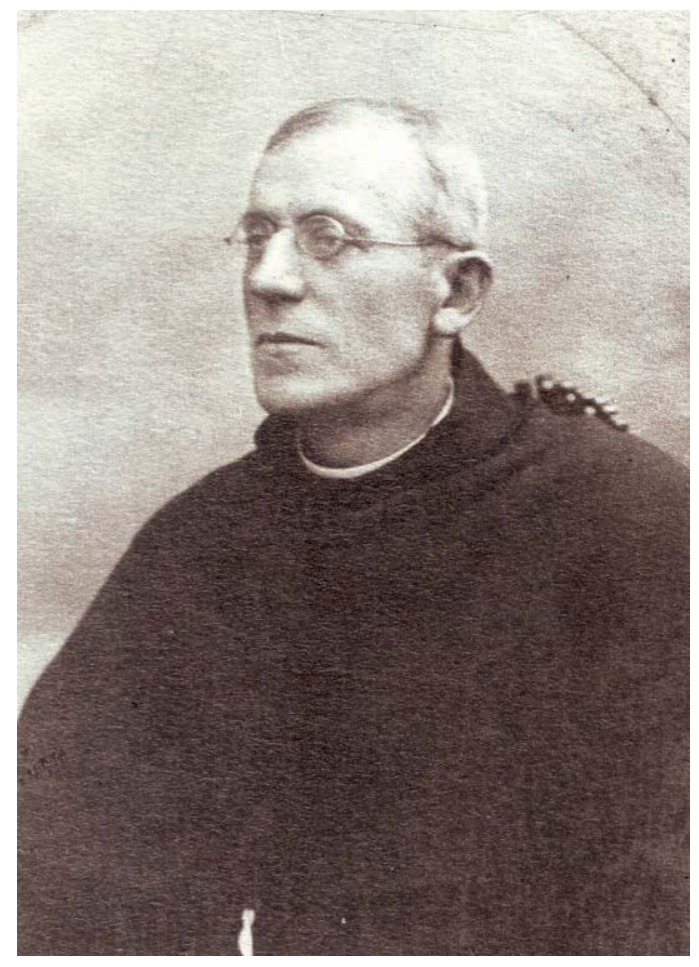

Sl. 1. Stjepan M. Ivančić (1852. - 1925.)

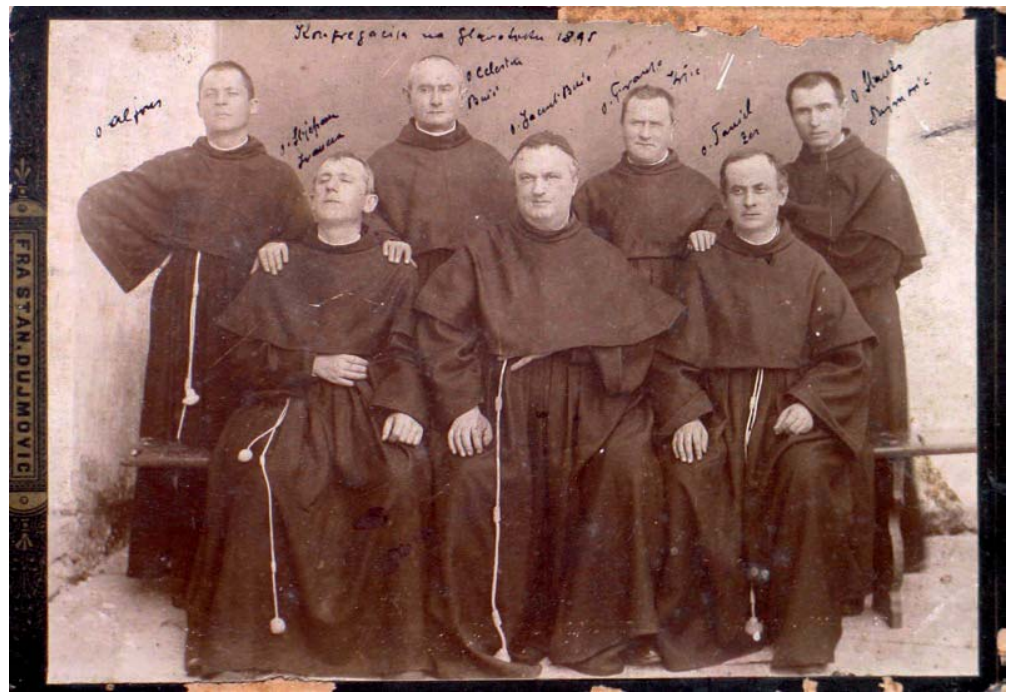

Sl. 2. Kongregacija franjevaca trećoredaca na Glavotoku 1895. godine (Stjepan M. Ivančić u prvom redu prvi slijeva) 


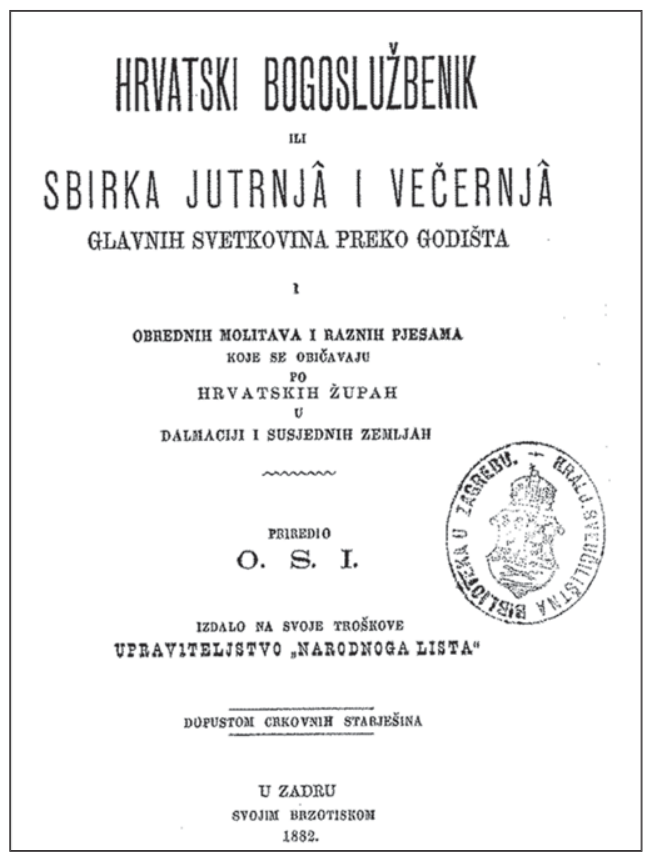

Sl. 3. Hrvatski bogoslužbenik (1882.)

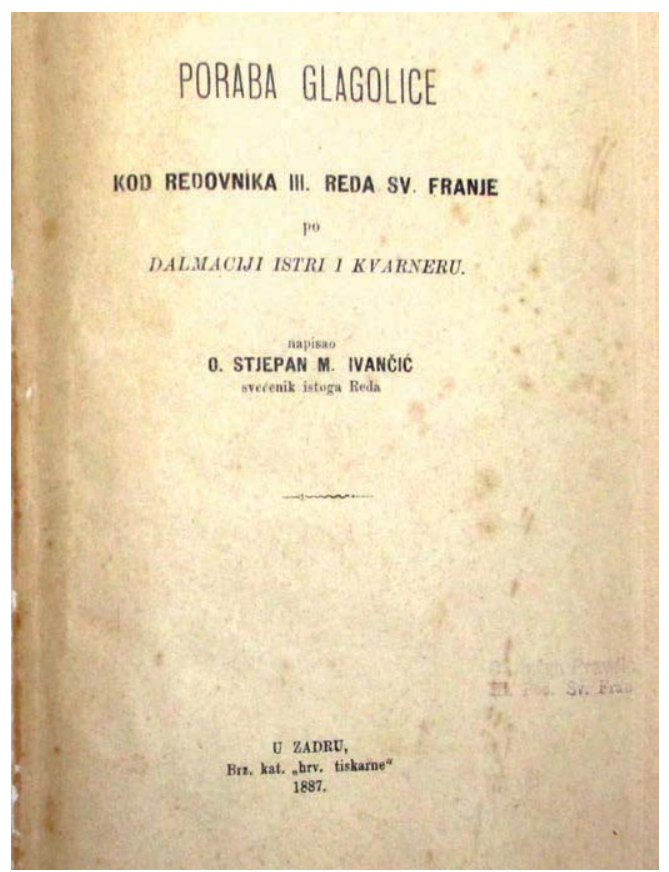

Sl. 4. Poraba glagolice kod redovnika III. Reda sv. Franje po Dalmaciji, Istri i Kvarneru (1887.) 


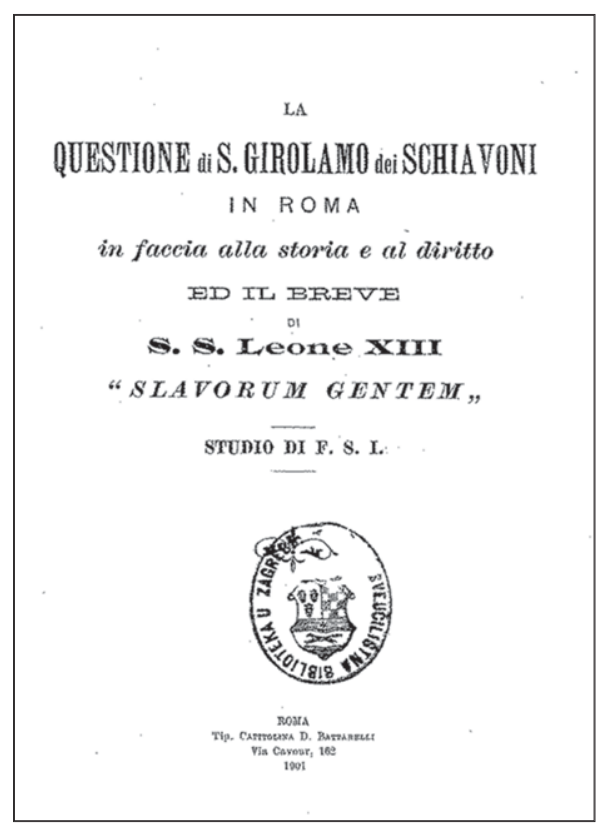

Sl. 5. La questione di s. Girolamo dei [!] Schiavoni in Roma in faccia alla storia e al diritto ed il breve di S. S. Leone XIII ,, Slavorum Gentem“ (1901.)

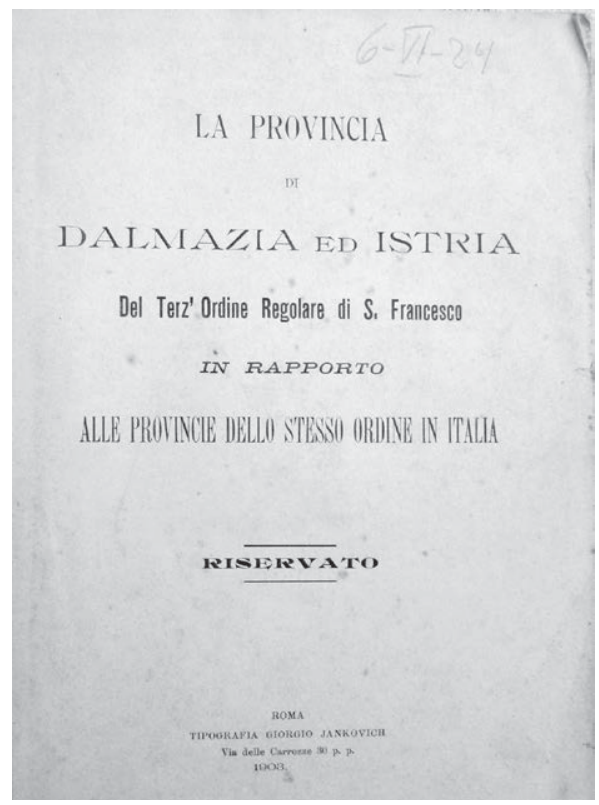

Sl. 6. Stjepan M. Ivančić - Dinko Šulina,

La provincia di Dalmazia ed Istria del Terz'Ordine Regolare di S. Francesco in rapporto alle provincie dello stesso Ordine in Italia. Riservato (1903.) 


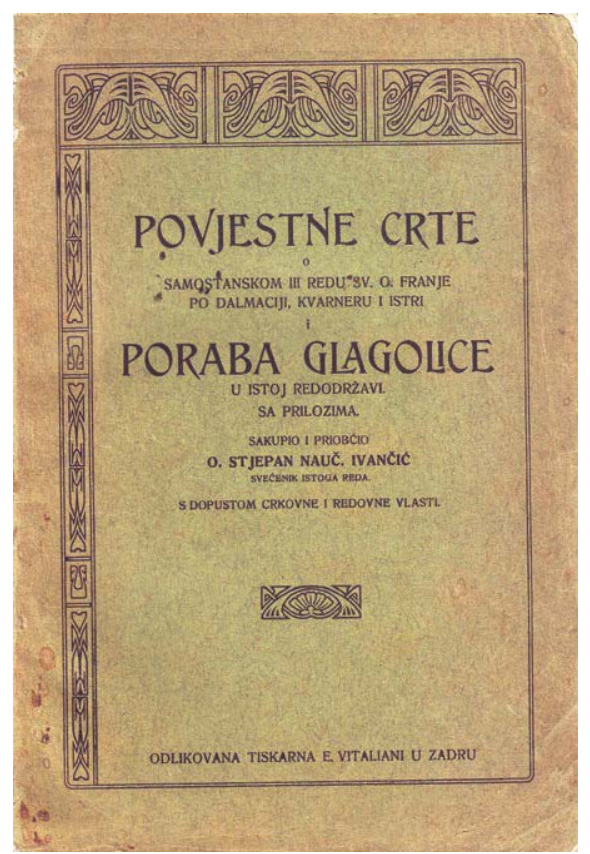

Sl. 7. Povjestne crte o samostanskom III Redu sv. O. Franje po Dalmaciji, Kvarneru i Istri i poraba glagolice u istoj redodržavi sa prilozima (1910.)

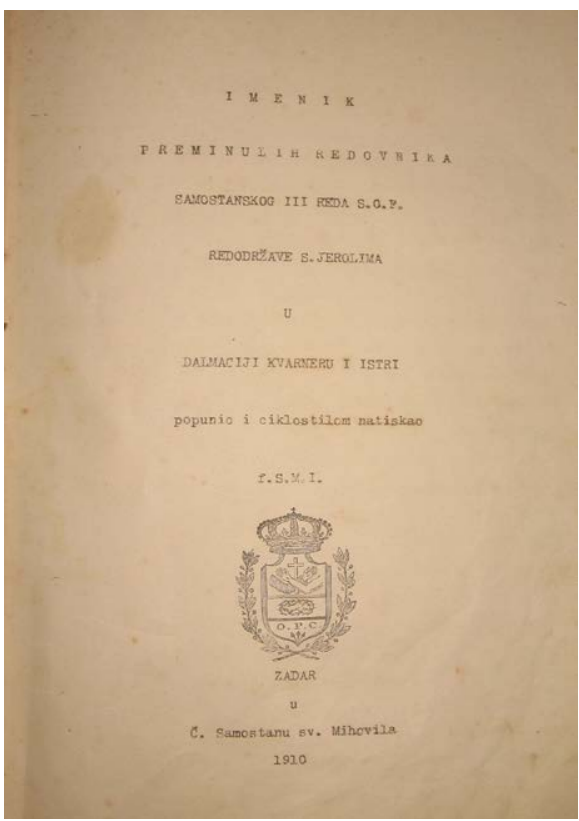

Sl. 8. Imenik preminulih redovnika samostanskog III reda S. O. F. Redodržave s. Jerolima u Dalmaciji, Kvarneru i Istri (1910.) 


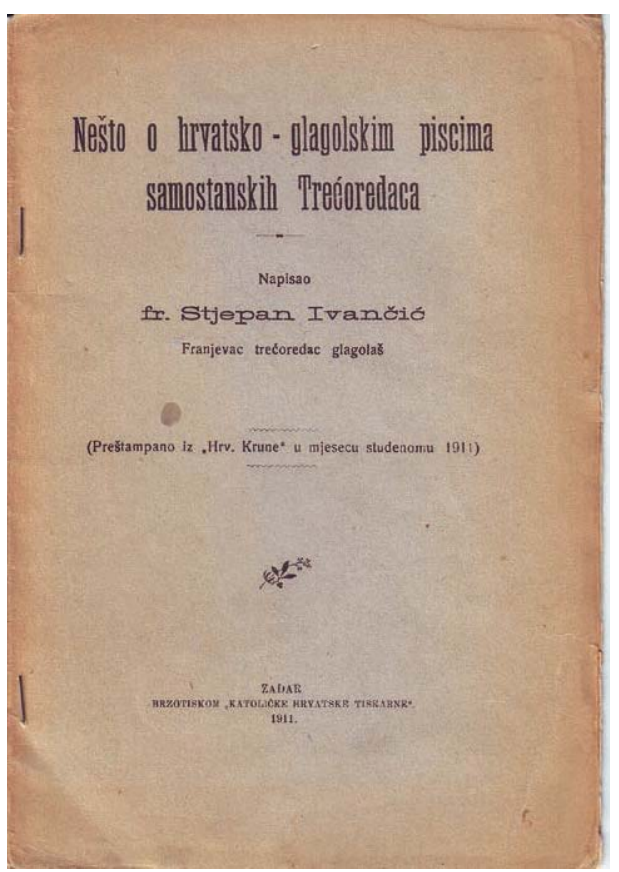

Sl. 9. Nešto o hrvatsko-glagolskim piscima samostanskih Trećoredaca (1911.)

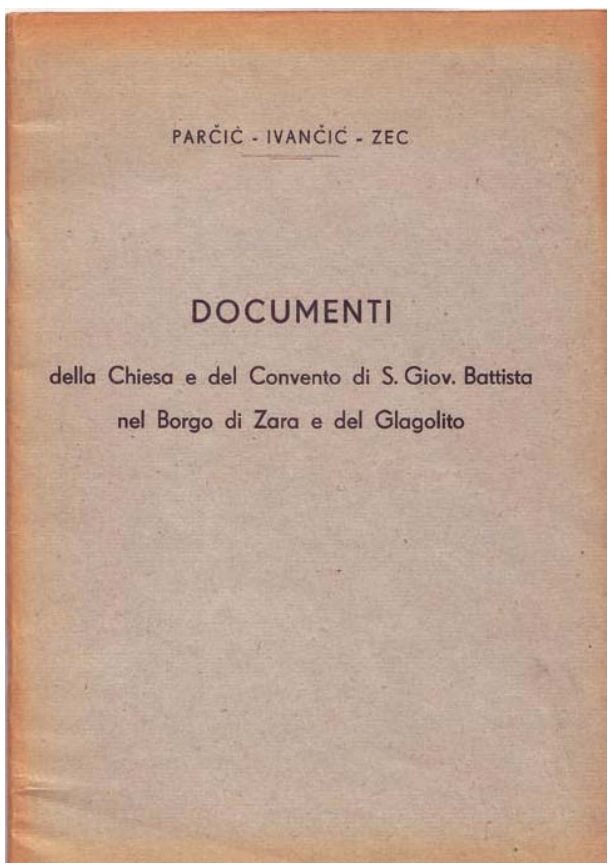

Sl. 10. Dragutin Antun Parčić - Stjepan M. Ivančić - Danijel Zec, Documenti della Chiesa e del Convento di S. Giov. Battista nel Borgo di Zara e del Glagolito (1950.) 


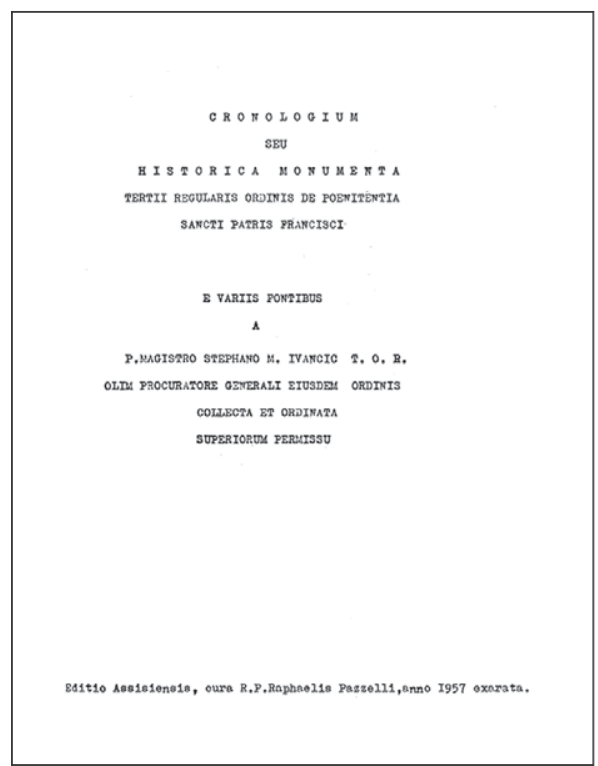

Sl. 11. Cronologium seu Historica monumenta Tertii Regularis Ordinis de Poenitentia Sancti Patris Francisci e variis fontibus (1957.)

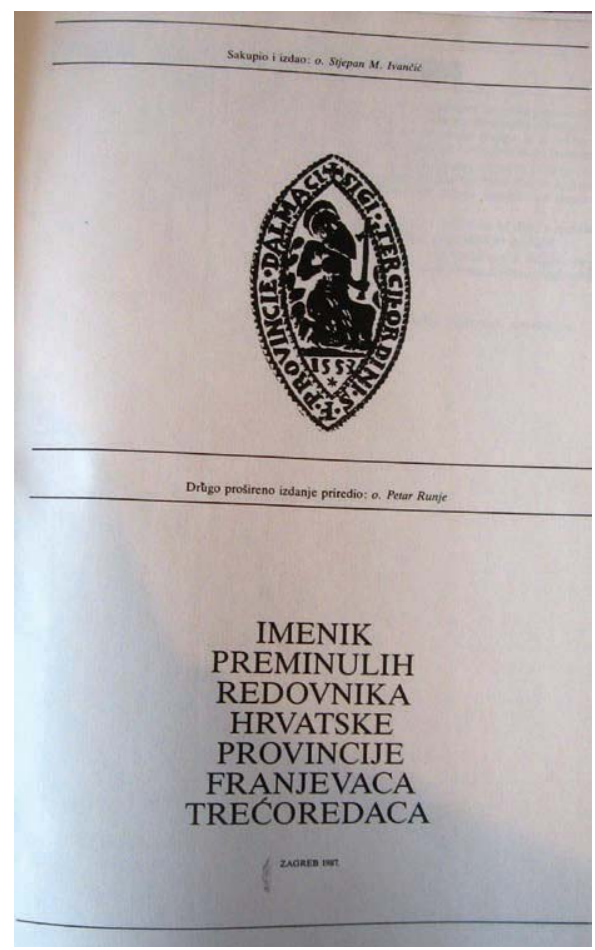

Sl. 12. Imenik preminulih redovnika Hrvatske provincije franjevaca trećoredaca (1987.) 


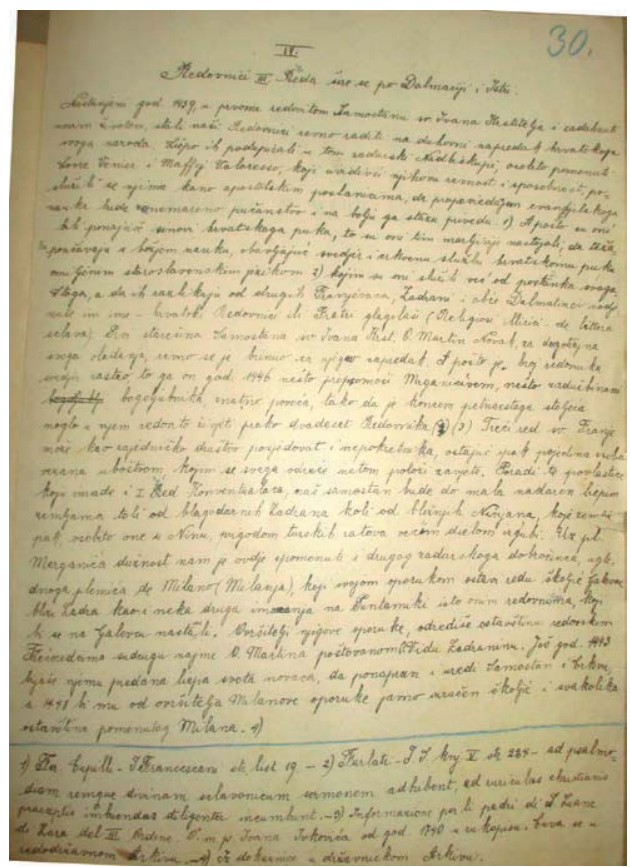

Sl. 13. Rukopis Ivančićeva djela Povjestne crte, poglavlje IV., str. 30. (Arhiv Provincije franjevaca trećoredaca glagoljaša, Zagreb)

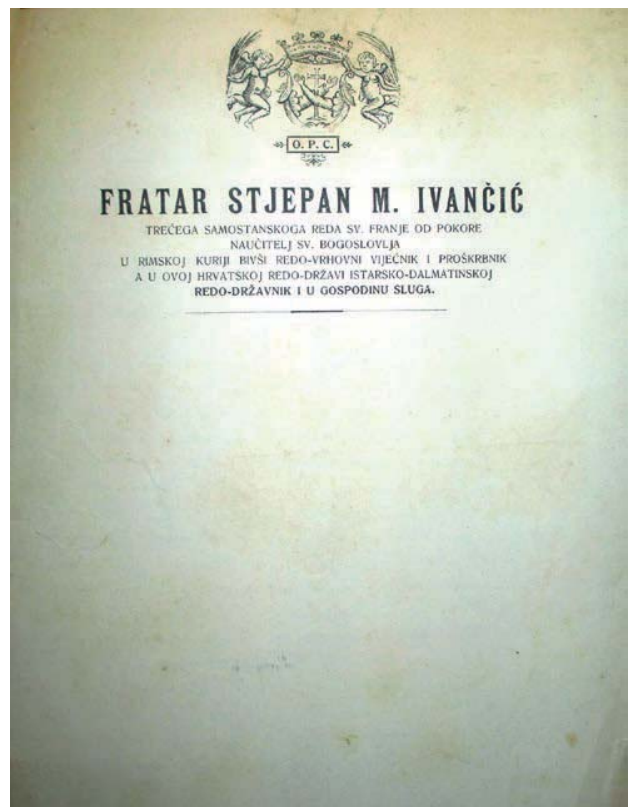

Sl. 14. Ivančićev memorandum

(Arhiv Provincije franjevaca trećoredaca glagoljaša, Zagreb) 
Bibliografija historiografskih radova Stjepana M. Ivančića

Poraba glagolice kod redovnika III reda Sv. Franje po Dalmaciji, Istri i Kvarneru. Katolička Dalmacija /Zadar/ XVIII (1887) 21: 2-3; XVIII (1887) 22: 1; XVIII (1887) 23: 2-3; XVIII (1887) 24: 2; XVIII (1887) 25: 2-3; XVIII (1887) 26: 2-3; XVIII (1887) 27: 2-3; XVIII (1887) 28: 2-3; XVIII (1887) 29: 2-3; XVIII (1887) 30: 2-3; XVIII (1887) 31: 2; XVIII (1887) 32: 2-3; XVIII (1887) 33: 2-3; XVIII (1887) 34: 2-3. Napomena: autor potpisan inicijalima: O. S. M. I.

Poraba glagolice kod redovnika III. Reda sv. Franje po Dalmaciji, Istri i Kvarneru. 1887. Napisao o. Stjepan M. Ivančić, svećenik istoga Reda. Zadar: Brzotiskom „Katoličke hrvatske tiskarne" (58 str.).

La questione di s. Girolamo dei [!] Schiavoni in Roma in faccia alla storia e al diritto ed il breve di S. S. Leone XIII „,Slavorum Gentem “. Studio di F. S. I. [= fra Stjepan Ivančić]. 1901. Roma: Tipografia Capitolina D. Battarelli $(132+254$ /= 386/ str. i 1 višestruko presavijeni list s faksimilom povijesne karte).

La questione di S. Girolamo de'Schiavoni in Roma in faccia alla storia e al diritto ed il breve di S. S. Leone XIII , Slavorum gentem “. Studio di F. S. I. [= fra Stjepan Ivančić]. 1901. (Seconda edizione). Roma: Tipografia Capitolina D. Battarelli $(132+254 /=386 /$ str. i 1 višestruko presavijeni list s faksimilom povijesne karte).

IVANCIC, Stefano M., SULINA, Domenico [= Stjepan M. Ivančić - Dinko Šulina]. 1903. La provincia di Dalmazia ed Istria del Terz' Ordine Regolare di S. Francesco in rapporto alle provincie dello stesso Ordine in Italia. Riservato. Roma: Tipografia Giorgio Jankovich (55 str.).

Povjestne crte o samostanskom III Redu sv. O. Franje po Dalmaciji, Kvarneru i Istri $i$ poraba glagolice u istoj redodržavi sa prilozima. Sakupio i priobćio o. Stjepan nauč. Ivančić, svećenik istoga Reda. S dopustom crkovne i redovne vlasti. Zadar: Odlikovana Tiskarna E. Vitaliani, 1910. $(255+231 /=486 /$ str. $)$

Imenik preminulih redovnika samostanskog III reda S. O. F. Redodržave s. Jerolima u Dalmaciji, Kvarneru i Istri. 1910. Popunio i ciklostilom natiskao f. S. M. I. [= fra Stjepan M. Ivančić]. Zadar: U č. Samostanu sv. Mihovila.

Nešto o hrvatsko-glagolskim piscima samostanskih Trećoredaca (piše fr. Stjepan Ivančić). Hrvatska kruna - glavno glasilo Stranke prava u Dalmaciji /Zadar/ XIX (1911) 95: [183]; XIX (1911) 96: [186]; XIX (1911) 97-98: [188]; XIX (1911) 99: [191]; XIX (1911) 100: [194]; XIX (1911) 101: [197]; XIX (1911) 103: [201].

Nešto o hrvatsko-glagolskim piscima samostanskih Trećoredaca. 1911. Napisao fr. Stjepan Ivančić, franjevac trećoredac glagolaš. (Preštampano iz Hrvatske krune u mjesecu studenomu 1911.). Zadar: Brzotiskom „Katoličke hrvatske tiskarne“ (18 str.).

(Dragutin Antun) PARČIĆ, (Stjepan M.) IVANČIĆ, (Danijel) ZEC. 1950. Documenti della Chiesa e del Convento di S. Giov. Battista nel Borgo di Zara e del Glagolito. Roma: Tipografia P. U. G. (53 str.).

Cronologium seu Historica monumenta Tertii Regularis Ordinis de Poenitentia Sancti Patris Francisci e variis fontibus a p. magistro Stephano M. Ivancic T. O. R. olim procuratore generali eiusdem Ordinis collecta et ordinata superiorum permissu. [Liber I. Pars I et II.]. Editio Assisiensis, cura R. P. Raphaelis Pazzelli, anno 1957 exarata, 
276 [287!] str. (manuscriptum in Archivio generale del Terz' Ordine Regolare di S. Francesco, Roma / Archivio della Curia Generalizia TOR, Roma; također i u: Biblioteca della Curia generale del Terzo ordine regolare di San Francesco, Roma).

Cronologium seu Historica monumenta Tertii Ordinis Regularis de Poenitentia S. Francisci. Liber II. Pars I et II. Editio Assisiensis, cura P. Raphaelis Pazzelli, anno 1957 exarata, 277-569+ 70 /Documenta varia Tertium ordinis regularem s. Francisci de poenitentia concernentia/ [=362] str. (manuscriptum in Archivio generale del Terz' Ordine Regolare di S. Francesco, Roma / Archivio della Curia Generalizia TOR, Roma; također i u: Biblioteca della Curia generale del Terzo ordine regolare di San Francesco, Roma).

Imenik preminulih redovnika Hrvatske provincije franjevaca trećoredaca. 1987. Sakupio i izdao: o. Stjepan M. Ivančić. Drugo prošireno izdanje priredio: o. Petar Runje. Zagreb: Provincijalat franjevaca trećoredaca.

\section{Bibliografija}

Izvori

Archivio generale del Terz' Ordine Regolare di S. Francesco, Roma / Archivio della Curia Generalizia TOR, Roma:

Cronologium seu Historica monumenta Tertii Regularis Ordinis de Poenitentia Sancti Patris Francisci e variis fontibus a p. magistro Stephano M. Ivancic T. O. R. olim procuratore generali eiusdem Ordinis collecta et ordinata superiorum permissu. 1903. [Liber I. Pars I et II.]. Roma (Editio Assisiensis, cura R. P. Raphaelis Pazzelli, anno 1957 exarata). Cronologium seu Historica monumenta Tertii Ordinis Regularis de Poenitentia S. Francisci. 1903. Liber II. Pars I et II. Roma (Editio Assisiensis, cura P. Raphaelis Pazzelli, anno 1957 exarata).

Arhiv franjevačkog samostana sv. Franje Asiškog, Krk:

RUNJE, Petar. 2007. Povijest Provincije franjevaca trećoredaca-glagoljaša dvadesetog stoljeća (strojopis). Ogulin.

Arhiv franjevačkog samostana sv. Marije, Glavotok (o. Krk):

Spisi 3 (1901. - 1930.)

Arhiv franjevačkog samostana sv. Jeronima, Martinšćica (o. Cres):

Spisi A I 4 (1901., 1902., 1907.)

Arhiv Provincije franjevaca trećoredaca glagoljaša, Zagreb:

Građa i rukopisi za povijest Reda i Provincije (Ivančić i Zec)

Lukoranska bilježnica o. Ante Nižića od 1911. do 1920. 


\section{Literatura}

***Častnomu otcu Stjepanu Ivančiću propovjedniku reda Male bratje u znak štovanja i harnosti na koncu korizmenog propoviedanja ovu pjesmu posvećuje creski puk 1880. Naša sloga XI/9 (1. V. 1880): 35.

***Franciscan Resources - Formation (bibliografija). http://www.franciscanfriarstor.com/ archive/resources/formation/stf_appendix.htm (posjet 10. 5. 2014).

***J. M. ${ }^{129}$ Poraba glagolice kod redovnika III. reda sv. Frane po Dalmaciji, Istri i Kvarneru. Napisao O. Stjepan M. Ivančić, svećenik istoga Reda. U Zadru 1887. u VIII. 58 strana. Pisac je svoje djelce posvetio: „Miloj redovskoj učećoj mladeži na pouku i bodrenje“. Smotra-mjesečnik za obću prosvjetu I/6 (1887): 370-371.

***Književni prikazi: Povjestne crte o samostanskom III redu sv. o. Franje po Dalmaciji, Kvarneru i Istri. Narodna prosvjeta - mjesečnik za školstvo, prosvjetu i književnost V/1 (1910): 18-19.

***Medjunarodni sastanak Trećaredaca sv. Frana. Pučki prijatelj I/20 (10. X. 1900): 159.

***Prijatelji: Mnogo poštovanom Otcu Stjepu Ivančiću korizmenomu prepovjedniku u Dubrovačkoj Stolnoj Crkvi god. 1901. Božja rieč. Croatia ${ }^{130}$ (Hrvatska) - Bog $i$ Domovina III/29 (1901): 3.

***Procesija s novim kipom Majke Božje u Krku. Pučki prijatelj V/22 [23] (10. XII. 1904): 188.

****Razne primorske viesti. Naša sloga XLIII/35 (29. VIII. 1912): 3.

***Svećenik: Svetište Bogorodičino na Trsatu u hrvatskom Primorju. Povijest svetišta i marijanski molitvenik. Obzor XXXVI/191 (1895): 3. ${ }^{131}$

***Veleučenom gospodinu Stjepanu Ivančiću otcu trećega reda prezaslužnom nam ovogodišnjem koriz. propovjedniku pri njegovu odlazku. Pjesma. Komižani. Komiža na koncu Korizme. 1883. Tiskarna I. Vodicke u Zadru. ${ }^{132}$

ANTOLJAK, Stjepan. 1992. Hrvatska historiografija do 1918. Knjiga I-II [Biblioteka Hrvatske povjesnice]. Zagreb: Nakladni zavod Matice hrvatske.

ANTOLJAK, Stjepan. 2004. Hrvatska historiografija [Posebna izdanja]. Drugo dopunjeno izdanje. Zagreb: Matica hrvatska.

Arhiv Provincije franjevaca trećoredaca - Regesti pergamena. 1980. Ur. Petar Runje. Zagreb: Provincijalat franjevaca trećoredaca (umnoženo kao prilog Vjesnika franjevaca trećoredaca glagoljaša, br. 3-4, 5-6/1979/ i br. 1-2 /1980/).

BADURINA, Anđelko. 1993a. Nepoznati Parčić. Zadarska smotra - časopis za kulturu, znanost i umjetnost XLII/3 (1993) /= Znanstveni skup „Dragutin Parčić hrvatski jezi-

\footnotetext{
129 Napomena: Možda inicijal treba biti I. M. (= Ivan Milčetić).

130 Napomena: „Privremeno na mjesto Katoličke Dalmacije.“

131 Napomena: U ovome se tekstu ne radi o fra Stjepanu M. Ivančiću, već o fra Franji Josipu Ivančiću (Varaždin, 26. IV. 1854. - Samobor, 16. X. 1915.).

132 Za opis v. MAŠTROVIĆ 1979: 322 (br. 732).
} 
koslovac i glagoljaš“ (u povodu 160. obljetnice rođenja i 90. obljetnice smrti), Zadar, 18. - 19. 10. 1992./: 155-182.

BADURINA, Anđelko. 1993b. Nepoznati Parčić. U DEROSSI 1993: 155-182.

BADURINA, Anđelko. 1993c. Nepoznati Parčić. U Antun Dragutin Parčić (1832. - 1902.) - hrvatski jezikoslovac i glagoljaš. Zbornik radova sa znanstvenoga skupa „Život i djelo Dragutina Parčića održanoga u Zadru i Preku 18. i 19. listopada 1992. " [Biblioteka Novaja i vethaja 4], ur. Julije Derossi, 155-182. Zagreb: Matica Hrvatska - Ogranak Zadar, Provincijalat franjevaca trećoredaca. Napomena: pretisak iz Zadarske smotre.

BADURINA, Antun [ABP]. 1976. Ivančić, fra Stjepan, STR (Cres, 28. VIII. 1852. - Zadar, 8. IV. 1925), pisac i govornik. U Franjo među Hrvatima. Zbornik radova franjevačkih zajednica u prigodi 750. obljetnice smrti sv. Franje Asiškoga (1226. - 1976.), ur. Hrvatin Gabrijel Jurišić. Zagreb: Središnji odbor za proslavu 750. obljetnice smrti sv. Franje Asiškoga, s. v. (232). Napomena: ABP = fra Antun (ne: Anđelko) Badurina Pavičić, STR.

BATINIĆ, Mijo Vjenceslav. 1881. - 1887. Djelovanje franjevaca u Bosni i Hercegovini za prvih šest viekova njihova boravka. I-III. Zagreb: Dionička tiskara.

Bibliografija Vjesnika franjevaca trećoredaca - 50 godišta: 1963. - 2013. 2014. Priredio i uredio fra Joso ŽIVKOVIĆ, suradnik fra Mirko MIŠKOVIĆ. Krk: Provincijalat franjevaca trećoredaca - Zagreb (= Vjesnik franjevaca trećoredaca glagoljaša L/4 [2013]) + CD-ROM.

BOGDAN, Jure (ur.). 2001. Papinski hrvatski zavod svetog Jeronima (1901. - 2001.) - Pontificium collegium Croaticum sancti Hieronymi (1901-2001). Zbornik u prigodi stoljetnice Papinskoga hrvatskog zavoda svetog Jeronima [Collectanea Croatico-Hieronymiana de Urbe, vol. 5]. Rim: Papinski hrvatski zavod svetog Jeronima.

BOGIŠIĆ, Rafo. 1965. Putovi glagolizma. Dr Marija Pantelić: Glagoljski tekstovi Bartola Krbavca, izd. „Radovi Staroslavenskog instituta u Zagrebu“, br. 5, 1964. Telegram jugoslavenske novine za društvena i kulturna pitanja VI/289 (12. XI. 1965): 4.

BOLONIĆ, Mihovil. 1965. Parčićeva tiskara u Glavotoku [Posebno izdanje]. Pogovor Vinko Antić. Rijeka: Matica hrvatska - Pododbor Rijeka.

BONEFAČIĆ, Kvirin Klement. 1903. Dragutin A. Parčić, 26. V. 1832. - 25. XII. 1902. Krk: Tisak tiskare „Kurykta“.

BORDONUS, Franciscus [BORDONI, Francesco]. 1658. Historia Tertii Ordinis S. Francisci. Cronologium fratrum, et sororum tam regularis quam secularis. Parmae: Typis Marii Vignae, MDCLVIII. (Riproduzione anastatica. A cura di Lino Temperini. Roma: Franciscanum, ${ }^{2} 1998$.).

BOTICA, Ivan, Tomislav GALOVIĆ. 2012. Fra Petar Runje - povjesničar franjevaštva i istraživač hrvatskog glagoljaštva. U Petar Runje, Prema izvorima II. Rasprave i članci o hrvatskim franjevcima trećoredcima glagoljašima [Krčki zbornik 68, Posebno izdanje 61; Biblioteka Novaja i vethaja 9], 241-263. Krk-Zagreb: Povijesno društvo otoka Krka, Provincijalat franjevaca trećoredaca glagoljaša.

BOTICA, Ivan, Vinko KOVAČIĆ, Kristijan KUHAR. 2015. Knjige posinovljenja, novicijata i zavjetovanja franjevaca trećoredaca glagoljaša otoka Krka (1717. - 1914.) [Monumenta glagolitica Tertii ordinis regularis sancti Francisci in Croatia, vol. II. I Glagoljski spomenici Trećega franjevačkog reda u Hrvatskoj, sv. 2.]. Zagreb: Provincija franjevaca trećoredaca glagoljaša, Staroslavenski institut. 
BRATULIĆ, Josip. 1990a. Mihovil Pavlinović i borba za glagoljicu u Dalmaciji u XIX. stoljeću. Forum - mjesečnik Razreda za književnost Hrvatske akademije znanosti $i$ umjetnosti XXIX-59/3-4: 385-400.

BRATULIĆ, Josip. 1990b. Mihovil Pavlinović i borba za glagoljicu u Dalmaciji u 19. stoljeću. U STANČIĆ 1990: 377-390.

BRATULIĆ, Josip. 1995. Leksikon hrvatske glagoljice. Zagreb: Minerva [Biblioteka Leksikoni].

BURIĆ, Josip. 1966. Iz prošlosti hrvatske kolonije u Rimu [Knjižnica „Novoga života“, sv. 1]. Rim: Knjižnica Novoga života.

BURIĆ, Josip. 1971. Kanonici hrvatskog kaptola sv. Jeronima u Rimu (1589-1901). Radovi Hrvatskog povijesnog instituta u Rimu III-IV: 91-158.

ČRNČIĆ, Ivan. 1868. Dvie razprave: Slovinski sveti Jerolim u Rimu a Rieka; i Drugo je Senj a drugo Segni. Napisao i na svietlo dao . U Trstu: Slovi Weisovimi.

ČRNČIĆ, Ivan. 1886a. Imena Slovjenin i Ilir u našem gostinjcu u Rimu poslije 1453 godine. Rad Jugoslavenske akademije znanosti i umjetnosti. Razredifilologičko-historički i filosofičko-juridički 13: 1-70.

ČRNČIĆ, Ivan. 1886b. Prilozi k razpravi: Imena Slovjenin i Ilir u našem gostinjcu u Rimu poslije 1453. god. Starine Jugoslavenske akademije znanosti i umjetnosti 18: 1-164.

ČRNČIĆ, Ivan. 1886c. Imena Slovjenin i Ilir u našem gostinjcu u Rimu poslije 1453 godine. U Zagrebu: Dionička tiskara (Preštampano iz 79. knj. Rada Jugoslavenske akademije znanosti i umjetnosti. Uz to: Ivan Črnčić, Prilozi k razpravi imena Slovjenin i Ilir u našem gostinjcu u Rimu poslije 1453. god. - preštampano iz 18. knj. Starina Jugoslavenske akademije znanosti i umjetnosti).

ČRNČIĆ, Ivan. 1896. Još dvoje o slovjenskom gostinjcu u Rimu izopačeno. Rad Jugoslavenske akademije znanosti i umjetnosti. Razredi filologičko-historički i filosofičkojuridički 44: 1-32.

DAROSLAV, v. BONEFAČIĆ, Kvirin Klement.

DEROSSI 1993. Dragutin Parčić (1832 - 1902): 160. obljetnica rođenja i 90. obljetnica smrti hrvatskoga jezikoslovca. Zbornik radova sa znanstvenoga skupa „Život i djelo Dragutina Parčića održanoga u Zadru i Preku 18. i 19. listopada 1992. “. Ur. Julije Derossi. Zadar: Matica hrvatska - Ogranak Zadar. Napomena: pretisak iz Zadarske smotre.

DIKLIĆ, Marjan. 2003. Don Ivo Prodan: političko djelovanje i parlamentarni rad. Zadar: Matica hrvatska Zadar.

FABIJANIĆ [FABIANICH], Donato. 1863-1864. Storia dei frati minori dai primordi della loro istituzione in Dalmazia e Bossina fino ai giorni nostri. Vol. I-II. Zara: Tip. Fratelli Battara.

GOSTL, Igor. 1998. Dragutin Antun Parčić [Mala knjižnica Matice hrvatske. Novi niz: kolo 8, knj. 47]. Zagreb: Matica hrvatska.

GREGOV, Ljudevit. 1965a. O našem glagolizmu - I. Vjesnik franjevaca trećoredaca (glagoljaša) III/3: 62-66.

GREGOV, Ljudevit. 1965b. O našem glagolizmu - II. Vjesnik franjevaca trećoredaca (glagoljaša) III/5: 108-111. 
GREGOV, Nikola. 1990. Školovanje u provinciji franjevaca trećoredaca glagoljaša [Novaja i vethaja 1]. Zagreb: Provincijalat franjevaca trećoredaca.

GREGOV, Nikola (prir.), Nikola MILČETIĆ. 1985. 60. godišnjica smrti o. Stjepana Marije Ivančića († 8. IV. 1925.). Vjesnik franjevaca trećoredaca (glagoljaša) XXII/4-5: 183-190. Napomena: neobjavljeni članak fra Nikole Milčetića (1891. - 1970.) i Prilog članku - razgovor s fra Kerubinom Sišulom (1892. - 1981.) o Ivančiću i popis Ivančićevih radova/bibliografija.

GRIJAK, Zoran. 2001. Politička djelatnost vrhbosanskog nadbiskupa Josipa Stadlera [Biblioteka Hrvatska povjesnica. III. Monografije i studije 14]. Zagreb: Hrvatski institut za povijest, Dom i svijet, Vrhbosanska nadbiskupija - Sarajevo.

IRIARTE, Lazaro [Lazaro de Aspurz]. 2013. Povijest franjevaštva. Predgovor hrvatskom izdanju Ante Logara, prijevod s talijanskoga Slavko Antunović [Volumina theologica: biblioteka Centra za koncilska istraživanja, dokumentaciju i informacije Kršćanska sadašnjost, sv. 33]. Zagreb: Hrvatska kapucinska provincija sv. Leopolda Bogdana Mandića, Kršćanska sadašnjost. Prevedeno prema: Storia del francescanesimo.

Iskoni bê slovo. Zbornik radova o glagoljici i glagoljašima zadarskog kraja i crkvi Svetog Ivana Krstitelja. 2001. Ur. Antun Badurina. Zagreb: Provincijalat franjevaca trećoredaca [Novaja i vethaja 7], Kršćanska sadašnjost.

IVANČIĆ, Stjepan Marija. 1886. Propovied na čast sv. Cirila i Metoda. Duhovni govornik I/1: 267-279.

IVANČIĆ, Stjepan Marija. 1901. [Dvojezična talijansko-hrvatska izjava S. Ivančića povodom provale nekih Dalmatinaca nastanjenih u Rimu u Zavod sv. Jeronima u Rimu]. Naša sloga XXXII/72 (13. IX. 1901): 4.

IVANČIĆ, Stjepan Marija. 1904a. Preuzvišenom pragospodinu Josipu Jurju Strossmayeru, prilikom skorog dara Trećem samostanskom redu sv. Franje u Dalmaciji i Istri. Kano gojitelju glagoljice. Glasnik Biskupije bosanske i sriemske XXXII/22: 172. ${ }^{133}$

IVANČIĆ, Stjepan Marija. 1904b. Preuzvišenom gospodinu Josipu Jurju Strossmayeru prilikom skorog dara Trećem samostanskom redu sv. Franje u Dalmaciji i Istri kao gojitelju glagoljice. Vrhbosna XVIII/22: 383.

IVANČIĆ, Stjepan Marija. 1906. Poslanica svojoj miloj braći, redovnicima samostanskoga Trećeg reda sv. otca Frane Redo-države Dalmacije i Istre. Zadar: Brzotiskom Katoličke hrvatske tiskarne.

IVANČIĆ, Stjepan Marija (prir.). 1907. Hrvatski bogoslužbenik ili Sbirka jutrnja i večernja glavnih svetkovina preko godine i obrednih molitava i raznih pjesama koje se običavaju po hrvatskih župah u Dalmaciji i susjednih zemaljah. Priredio O. S. I. [= Stjepan Marija Ivančić], prigledao N. B. [= Nikola Batistić]. 3. popunjeno izd. Zadar: Upraviteljstvo „Narodnoga lista“ (Zadar 1882., ${ }^{2} 1893$.).

IVANČIĆ, Stjepan Marija. 1907. Plači i tuguj o creski puče nad preranom smrti tvoga dobrotvora m. p. o. Serafina Belamarića provincijala Male braće konventualaca. Na ime creskih kopača fr. Stjepo M. Ivančić cresanin Provincijal Trećoredskih franjevaca u Zadru. Izdao Stj. Ivančić. Zadar: Tisak Š. Artale. ${ }^{134}$

\footnotetext{
133 Autor potpisan kao: fr. Stjepo M. Ivančić.

134 Za opis v. MAŠTROVIĆ 1979: 436 (br. 1014).
} 
IVANIŠEVIĆ, Frano. 1930. Pobjeda glagolice kroz tisućljetnu borbu. Split: Jugoslavenska matica [Knjižnica Jugoslavenske matice glavne podružnice u Splitu, br. 10].

JELIĆ, Luka. 1902a. Hrvatski zavod u Rimu. Zagreb: Kraljevska zemaljska tiskara. Napomena: poseban otisak iz Vjestnika Kr. hrv.-slav.-dalm. zemaljskog arkiva IV/1 (1902).

JELIĆ, Luka. 1902b. L'Istituto croato a Roma: studio storico. Appendice: Avvenimenti recentissimi per cura di Vinko Kisić. Zara: „Hrvatska knjižarnica“ editrice, Tipografia del „Narodni List““.

JELIĆ, Luka. 1906. Fontes historici liturgiae Glagolito-Romanae a XIII ad XIX saeculum, Veglae: Sumptibus Societatis libris Catholicis edendis Zagrabiae.

JEROLIMOV, Pavao. 2008. Na današnji dan: Stjepan Marija Ivančić. Zadarski list. Mrežno izdanje: 27. VIII. 2008. (posjet 10. 6. 2015)

JURIŠIĆ, Pavo. 2011. Posljednji pobornici glagoljice. Kačić-zbornik Franjevačke provincije Presvetoga Otkupitelja / Acta Provinciae ss. Redemptoris Ordinis fratrum minorum in Croatia XLI-XLIII/2009-2011 /=Zbornik u čast Emilija Marina/: 1013-1030.

KAPITANOVIĆ, Vicko. 2006. La storiografia dell'Ordine francescano e delle congregazioni religiose di ispirazione francescana in Croazia. U Crkva i društvo uz Jadran: vrela $i$ rezultati istraživanja. Zbornik radova Međunarodnog znanstvenog skupa, Split, 21. - 22. IX. 2001. - Chiesa e societa nell'area Adriatica: fonti e bilancio delle ricerche. Atti dell convegno internazionale, Split, 21-22. IX. 2001. [Katedra crkvene povijesti, knj. 2, Bogoslovna biblioteka, knj. 23], prir. Vicko Kapitanović, 187-232. Split: Katolički bogoslovni fakultet Sveučilišta u Splitu, Služba Božja.

KATIČIĆ, Radoslav. 1999. Na kroatističkim raskrižjima [Biblioteka Croaticum, sv. 1]. Zagreb: Hrvatski studiji - Studia Croatica Sveučilišta u Zagrebu. (2011.2)

KISIĆ, Vinko. 1902. Najnoviji dogodjaji: dodatak $k$ razpravi Hrvatski zavod u Rimu. Zadar: Hrvatska knjižarnica [Hrvatski zavod u Rimu: dodatak Najnoviji dogadjaji. Acta Hieronymiana].

KOKŠA, Đuro. 2001. Hrvatska crkva svetog Jeronima [u Rimu]. Prijevod Niko Šošić. Zagreb: Družba „Braća Hrvatskoga Zmaja“ [Biblioteka Acta et studia draconica, knj. VIII.]. Prijevod djela: San Girolamo degli Schiavoni (1971.).

KOSIĆ, Ivan. 2010. Ivančićev zbornik: hrvatskoglagoljski neliturgijski rukopis iz XIV./ $X V$. st. Doktorska disertacija, mentor: akademik Eduard Hercigonja. Zagreb: Filozofski fakultet Sveučilišta u Zagrebu.

KOVAČIĆ, Slavko. 1985. Don Frane Bulić i glagoljica. Crkva u svijetu XX/2: 169-181.

KOVAČIĆ, Slavko. 1993. Glagoljsko bogoslužje i glagoljaši na području srednje Dalmacije od XVI. do XX. stoljeća. Kačić - zbornik Franjevačke provincije Presvetoga Otkupitelja / Acta Provinciae ss. Redemptoris Ordinis Fratrum Minorum in Croatia XXV /= Zbornik u čast fra Karla Jurišićal XXV/25: 449-459.

KOVAČIĆ, Slavko. 2001a. Hrvatski kolegij u Rimu prije apostolskog pisma Slavorum gentem. U BOGDAN 2001: 17-98.

KOVAČIĆ, Slavko. 2001b. Mučni počeci sadašnjega Papinskog hrvatskog zavoda sv. Jeronima u Rimu od preustroja g. 1901. i neslužbenog otvaranja g. 1911. do naglog prekida djelovanja g. 1915. U BOGDAN 2001: 99-124. 
KULUNDŽIĆ, Zvonimir. 1965. Još o ,putovima glagoljizma“. Gdje je naučna istina?. Telegram-jugoslavenske novine za društvena i kulturna pitanja VI/294 (17. XII. 1965): 2.

KULUNDŽIĆ, Zvonimir. 1970a. Tragedija hrvatske historiografije: o falsifikatorima, birokratima, negatorima itd--- itd--- hrvatske povijesti. Zagreb: Vlast. nakl.

KULUNDŽIĆ, Zvonimir. 1970b. Tragedija hrvatske historiografije: o falsifikatorima, birokratima, negatorima itd--- itd--- hrvatske povijesti. 2. popravljeno i prošireno izd. Zagreb: Vlast. nakl.

LIEPOPILI, Ante. 1902. Bibliografija: La questione di S. Girolamo de' Schiavoni in Roma in faccia alla storia ed al diritto. Studio di F. S. I. [Roma Tip. Capitolina 1901]. List Dubrovačke biskupije II/2: 29-31. ${ }^{135}$

LUCONI, Raniero (Raynerius). 1935. Il Terzo Ordine Regolare di S. Francesco. Con prefazione del Prof. Giovanni Joergensen ed illustrazioni di Oscar Marziali. Macerata: Casa editrice Bisson \& Leopardi.

LUCONI, Raynerius. 1944. Comitia generalia Tertii Ordinis Regularis S. Francisci eorumque Acta selecta (ex Analectis ordinis anni 1944). Romae: Apud Curiam generalem.

MAGJEREC, Giorgio [= Juraj]. 1953a. Istituto di s. Girolamo degli Illirici (1453-1953). Roma: Tipografia della Pontificia Università Gregoriana.

MAGJEREC, Juraj. 1953b. Hrvatski zavod sv. Jeronima u Rimu (Collegium S. Hieronymi Illyricorum in Urbe). S dodatkom: Jubilejske proslave (1453-1953). Rim: Hrvatski zavod sv. Jeronima (Tiskara Papinskog sveučilišta Gregoriane).

MARKOVIĆ, Vladimir. 1975. Znameniti ljudi Cresa i Lošinja. Otočki ljetopis Cres-Lošinj 2: 377-383. (Stjepan Ivančić, pisac, franjevac /Cres, 1851 - ?/ str. 379)

MAŠTROVIĆ, Vjekoslav. 1949. Jadertina Croatica. Bibliografija knjiga, časopisa $i$ novina izdanih na hrvatskom ili srpskom jeziku u Zadru. I. dio: Knjige [Hrvatska bibliografija]. Zagreb: Jugoslavenska akademija znanosti i umjetnosti.

MAŠTROVIĆ, Vjekoslav. 1954. Jadertina Croatica. Bibliografija knjiga, časopisa i novina izdanih na hrvatskom ili srpskom jeziku u Zadru. II. dio: Časopisi i novine [Hrvatska bibliografija. Niz C, knj. 2, sv. 2.]. Zagreb: Jugoslavenska akademija znanosti i umjetnosti.

MAŠTROVIĆ, Vjekoslav. 1979. Zadarska oznanjenja iz XVIII, XIX. i početka XX. stoljeća (Jadertina Croatica) [Zavod za povijesne znanosti Istraživačkog centra Jugoslavenske akademije znanosti i umjetnosti u Zadru. Djela, knj. 6]. Zagreb: Jugoslavenska akademija znanosti i umjetnosti.

MILČETIĆ, Ivan, v. i: ***J. M. Poraba glagolice kod redovnika III. reda sv. Frane po Dalmaciji, Istri i Kvarneru.

MILČETIĆ, Ivan. 1890. Prilozi za literaturu hrvatskih glagolskih spomenika (prvi prilog). Starine JAZU XXIII: 39-153.

MILČETIĆ, Ivan. 1910. Franjevci i glagolica. Suvremenik-mjesečnik Družtva hrvatskih književnika $\mathrm{V} / 3: 201 .{ }^{136}$

135 Napomena: Autor je potpisan inicijalima: A. L.

136 Napomena: Autor je potpisan inicijalima: I. M. 
MILČETIĆ, Ivan. 1911. Hrvatska glagoḷska bibliografija (I. dio. Opisi rukopisâ, sa dva priloga i dodatkom). Starine JAZU XXXIII: I-XIV + 1-505.

MILČETIĆ, Nikola [MILCETIC, Nicolaus]. 1954. P. Stephanus Maria Ivancic T. O. R. Analecta Tertii Ordinis Regularis Sancti Francisci 6: 341-345.

MILINOVIĆ, Šimun. 2004. Hrvatske uspomene iz Dalmacije. Povijesne rasprave. Prir. Milan Glibota. Zagreb: Školska knjiga, Matica hrvatska - Ogranak Imotski.

MILOVČIĆ, Ivan. 1990. Glagolitica Hieronymiana. Croatica Christiana periodica XIV/25: 165-178.

Mjesec dana na nauku kod svetoga Josipa ili kratka zabavna štivenja kroz mjesec ožujak o životu svetaca. 1878. Prievod iz talijanskoga. Zadar: Tiskom Spira Artale. ${ }^{137}$ (Preveo s talijanskog Stjepan M. Ivančić). ${ }^{138}$

PANTELIĆ, Marija [Agnezija]. 1964. Glagoljski kodeksi Bartola Krbavca. Radovi Staroslavenskog instituta 5: 5-98 + 24 tab.

PANTELIĆ, Marija Agnezija. 2013. Hrvatsko glagoljsko srednjovjekovlje [Odjel za hrvatski glagolizam, knj. 3]. Prir. Petar Bašić i Roman Turčinović. Zagreb: Djela Instituta za ekumensku teologiju i dijalog ,Juraj Križanić“ Katoličkog bogoslovnog fakulteta Sveučilišta u Zagrebu, Kršćanska sadašnjost, Družba sestara milosrdnica svetog Vinka Paulskog u Zagrebu.

PAPONJA, Ivan. 1980. O. Stjepan Ivančić, život i djela. Diplomski rad, mentor: dr. Franjo Šanjek. Zagreb: Katolički bogoslovni fakultet.

PAPONJA, Ivan. 2001. Ivančić, fra Stjepan, povjesničar (Cres, 29 [!]. 8. 1852. - Zadar, 8. 4. 1925.). Hrvatski franjevački biografski leksikon [I (A - K)]. Ur. Vicko Kapitanović, Emanuel Hoško. Zagreb: Vijeće franjevačkih zajednica, s. v. (316-317). Napomena: radna verzija Leksikona objavljena u pdf formatu.

PAPONJA, Ivan. 2010. Ivančić, Stjepan Marija, povjesničar, pisac i propovjednik (Cres, 28. VIII. 1852 - Zadar, 8. IV. 1925). Hrvatski franjevački biografski leksikon. Ur. Franjo Emanuel Hoško, Pejo Ćošković, Vicko Kapitanović. Zagreb: Leksikografski zavod „Miroslav Krleža“ i Vijeće franjevačkih zajednica Hrvatske i Bosne i Hercegovine, s. v. (244-245).

PARČIĆ, Dragutin Antun (prir.). 1893. Rimbski Misalb slavênbskimb ezikomb prêsv. G. N. Urbana Papi VIII povelêniemb izdanb Missale Romanum Slavonico idiomate ex decreto sacrosancti Concilii Tridentini. Rim: Congr. de Propaganda Fide, Ex typographia polyglotta (Pretisak III. izdanja /Rim, 1905./ - Podgorica: Nevladina organizacija „Ivan Mažuranić“" - Fond za manjine Crne Gore, 2011.).

PAZZELLI, Raffaele. 1958. Il Terz'ordine regolare di s. Francesco attraverso i secoli. Roma: Curia Generalizia dell'Ordine (Rielaborazione critica e sviluppo dell'opera storica del p. Raniero Luconi T. O. R.).

PETROVIĆ, Ivanka. 1972. Bogorodičina čudesa u Ivančićevu zborniku, hrvatskoglagoljskom spomeniku 14/15. st. Radovi Staroslavenskog instituta 7: 123-210 + tab.

137 Za opis knjige v. MAŠTROVIĆ 1949: 118.

138 Za autorstvo prijevoda v. GREGOV I MILČETIĆ 1985: 190. 
PETROVIĆ, Ivanka. 2005. Ivančić, Stjepan Marija, crkveni povjesničar, glagoljaš (Cres, 28. VIII. 1852 - Zadar, 8. IV. 1925). Hrvatski biografski leksikon 6. [I - Kal]. Ur. Trpimir Macan. Zagreb: Leksikografski zavod „Miroslav Krleža“, s. v. (125-126).

Prigodnice biskupu Strossmayeru objavljene u Glasniku od 1874. do 1905. 2005. Izabrao i priredio Mirko Ćurić [Biblioteka Strossmayerova godina, knj. 2]. Đakovo: Matica hrvatska - Ogranak Đakovo, Đakovački kulturni krug, Biskupija đakovačka i srijemska, Gradsko poglavarstvo Đakovo.

PRODAN, Ivo. 1900a. Uspomene X. Borba za glagolicu. I. dio: Poviest glagolice i nje izvori. Zadar: Tiskarnica Vitaliani (Spisi D. Iva Prodana).

PRODAN, Ivo. 1900b. Contro il glagolito. Alcune osservazioni. Zara: Edizione privata, modo di manoscritto (Coi tipi della stamperia cattolica croata).

PRODAN, Ivo. 1904. Je li glagolica pravo svih Hrvata?. Zadar.

RADIĆ, Ignacij. 1954. Iz mojih uspomena. Vjesnik Provincije otaca trećoredaca I/2: 3-4.

RADIĆ, Ignacij. 1963a. Fra Dragutin Parčić (napisano 1962.). Vjesnik franjevaca trećoredaca (glagoljaša) I/1: 6-8.

RADIĆ, Ignacij. 1963b. Fra Dragutin Parčić (nastavak). Vjesnik franjevaca trećoredaca (glagoljaša) I/2: 18-21.

RADIĆ, Ignacij. 1963c. Fra Dragutin Parčić (svršetak). Vjesnik franjevaca trećoredaca (glagoljaša) I/3: 40-42.

RADIĆ, Ignacij. 1963d. O. Stjepan nauč. Ivančić (1852. - 1925.). Život i djela. Vjesnik franjevaca trećoredaca glagoljaša I/5: 66-70.

RADIĆ, Ignacij. 1963e. O. Stjepan nauč. Ivančić. II. Djela. Vjesnik franjevaca trećoredaca (glagoljaša) I/6: 90-94.

RELJANOVIĆ, Marijo. 2001. Enciklika Grande Munus i pitanje obnove glagoljaštva u Dalmaciji. Radovi Zavoda povijesne znanosti HAZU u Zadru 43: 355-374.

RUNJE, Petar. 1985. Novi prilozi za život o. Mateja Bošnjaka-Mastilića, franjevca trećoreca (o. 1430-1525). Croatica Christiana Periodica IX/16: 107-118.

RUNJE, Petar. 1990. Prema izvorima [Novaja i vethaja 2]. Zagreb: Provincijalat franjevaca trećoredaca.

RUNJE, Petar. 1993. Dio „Pisma vjernicima I.“sv. Franje u srednjovjekovnom hrvatskom prijevodu u Ivančićevu zborniku. Kačić - zbornik Franjevačke provincije Presvetoga Otkupitelja / Acta Provinciae ss. Redemptoris Ordinis Fratrum Minorum in Croatia XXV /= Zbornik u čast fra Karla Jurišića/ XXV/25: 437-448.

RUNJE, Petar. 1995. Parte della „Lettera I ai fedeli“ di San Francesco in una traduzione croata medievale contenuta nel „Codice Ivančić“. Analecta Tertii Ordinis Regularis Sancti Francisci XXVI/156: 61-70.

RUNJE, Petar. 2007. Povijest Provincije franjevaca trećoredaca-glagoljaša dvadesetog stoljeća (strojopis). Ogulin: umnoženo u vlastitoj nakladi (primjerak u posjedu autora i u Arhivu franjevačkog samostana sv. Franje Asiškog, Krk).

RUNJE, Petar. 2008. Ivančićev zbornik franjevačke provenijencije. Vjesnik franjevaca trećoredaca glagoljaša XLV/4: 212-215. 
RUNJE, Petar. 2012. Prema izvorima II. Rasprave i članci o hrvatskim franjevcima trećoredcima glagoljašima [Novaja i vethaja 9, Krčki zbornik 68, Posebno izdanje 61]. Ur. Tomislav Galović. Zagreb: Provincijalat franjevaca trećoredaca, Povijesno društvo otoka Krka.

SOKOLIĆ, Julijano. 2008. Zavičajni kalendar cresko-lošinjskoga otočja (prvo izdanje) [Otočki ljetopis Cres-Lošinj, sv. 15]. Mali Lošinj: Katedra Čakavskog sabora Cres-Lošinj, Glosa, Rijeka (izvršni nakladnik).

SPINČIĆ, Vjekoslav. 1925. Ivančić o. Stjepan. U Znameniti i zaslužni Hrvati te pomena vrijedna lica u hrvatskoj povijesti od 925-1925. Sa pregledom povijesti Hrvatske, Bosne i Istre, hrvatske književnosti i razvitka hrvatskog jezika, te hrv. vladara, hercega, banova i biskupa, kao uvodom. Sa 9 zasebnih slika, te 421. slikom u tekstu. Prigodom proslave 1000-godišnjice hrvatskoga kraljevstva, ur. Emilij Laszowski, 114. Zagreb: Odbor za izdanje knjige „Zaslužni i znameniti Hrvati 925-1925.“ - Tisak i oprema Hrvatskog štamparskog zavoda d. d. u Zagrebu (Reprint 1990. Zagreb: „August Cesarec" [Posebna izdanja]).

SPINČIĆ, Vjekoslav. 1926. Crtice iz hrvatske književne kulture Istre. Zagreb: Tisak Nadbiskupske tiskare (Reprint 1984. Zagreb: Kršćanska sadašnjost).

STANČIĆ, Nikša (prir.). 1993. Mihovil Pavlinović u politici i književnosti [Biblioteka Posebna izdanja]. Zagreb: Nakladni zavod Globus, Zavod za hrvatsku povijest Filozofskog fakulteta Sveučilišta u Zagrebu, SIZ kulture općine Makarska.

STRČIĆ, Petar. 2007. Kratki pregled povijesti Cresa do 1947. godine. U Stotinu godina hrvatske škole u Cresu (1907. - 2007.), ur. Mirko Parat, 9-88. Cres: Osnovna škola Frane Petrića.

STRECHA, Mario. 1995. „Collegium hieronymianum pro croatica gente“: svetojeronimska afera. Radovi Zavoda za hrvatsku povijest Filozofskog fakulteta Sveučilišta u Zagrebu 28: 158-189.

STRECHA, Mario. 1997. Katoličko hrvatstvo. Počeci političkog katolicizma u banskoj Hrvatskoj (1897. - 1904.) [Biblioteka Homines, tempora, loci]. Zagreb: Barbat.

STROHAL, Rudolf. 1915. Hrvatska glagolska knjiga. Zagreb: Vlastita naklada (Tiskara Merkur).

ŠTEFANIĆ, Vjekoslav. 1956. Glagoljaši u Kopru g. 1467-1806. Starine 46: 203-329 + 7 tab.

ŠTEFANIĆ, Vjekoslav. 1964. Glagoljski Transit svetog Jeronima u starijem prijevodu. Radovi Staroslavenskog instituta 5: 99-161.

ŠTEFANIĆ, Vjekoslav. 1965. Kulundžić o putovima glagoljizma. Telegram - jugoslavenske novine za društvena i kulturna pitanja VI/296 (31. XII. 1965).

TANDARIĆ, Josip Leonard. 1993. Hrvatsko-glagoljska liturgijska književnost. Rasprave i prinosi [Odjel za hrvatski glagolizam, knj. 1]. Prir. Petar Bašić, Stjepan Damjanović, Marko Mišerda. Zagreb: Djela Instituta za ekumensku teologiju i dijalog „Juraj Križanić“ Katoličkog bogoslovnog fakulteta u Zagrebu, Kršćanska sadašnjost, Provincijalat franjevaca trećoredaca.

TOMASOVIĆ, Mirko. 1994. Slike iz povijesti hrvatske književnosti [Mala knjižnica Matice hrvatske. Novi niz: kolo II, knj. 9]. Zagreb: Matica hrvatska. 
TUMPIĆ, Mijo. 1943. Zavod sv. Jeronima u Rimu. Croatia sacra - arhiv za crkvenu poviest Hrvata XI-XII/20-21: 340-349.

VELČIĆ, Franjo. 2015. Talijansko-hrvatska polemika o glagoljici i vatikanska diplomacija krajm 19. i početkom 20. stoljeća. U Hrvatsko glagoljaštvo u europskom okružju. Zbornik radova Međunarodnoga znanstvenoga skupa povodom 110. obljetnice Staroslavenske akademije i 60. obljetnice Staroslavenskoga instituta, Krk, 5. i 6. listopada 2012. [Bibliotheca Glagolitica Croatica, knj. 2.], ur. Vesna Badurina Stipčević, Sandra Požar, Franjo Velčić, 75-100. Zagreb: Staroslavenski institut.

VLADOVIĆ, Šime. 1964a. Prošlogodišnje proslave Ćirilometodskog jubileja - Provincija Trećoredaca Glagoljaša. Vjesnik franjevaca trećoredaca (glagoljaša) II/3: 56-61. Napomena: članak potpisan pod pseudonimom Trećoredac-Glagoljaš Marčoba. ${ }^{139}$

VLADOVIĆ, Šime. 1964b. Prošlogodišnje proslave Ćirilometodskog jubileja - Provincija Trećoredaca Glagoljaša (kraj). Vjesnik franjevaca trećoredaca (glagoljaša) II/4: 7679. Napomena: članak potpisan pod pseudonimom Trećoredac-Glagoljaš Marčoba.

VLADOVIĆ, Šime. 1965. Nekrologij naše Provincije. Vjesnik franjevaca trećoredaca (glagoljaša) III/2: 41-45. Napomena: članak potpisan pod pseudonimom Marčoba.

VUKIĆ, Ante. 1912. Povjesne crte o trećem redu svetoga Franje i poraba glagolice u istoj redodržavi, sa prilozima. Izdao Stjepan Ivančić. Prava Crvena Hrvatska VIII/381: 1-2.

Za glagolicu. Pokrajinski sastanak u Splitu dneva 6. srpnja 1902. 1902. Split: Brzotiskom „Narodne tiskare“ [i. e. 1903.].

ZLATOVIĆ, Stipan (Stjepan). 1888. Franovci Države Presvet. Odkupitelja i hrvatski puk u Dalmaciji. Zagreb: C. Albrecht.

ŽUBRINIĆ, Darko. 1996. Hrvatska glagoljica: biti pismen - biti svoj. Drugo izdanje. Zagreb: Hrvatsko književno društvo sv. Jeronima (sv. Ćirila i Metoda), Element.

139 Pseudonim razriješen na temelju vrijedne, pouzdane i vrlo korisne Bibliografije Vjesnika franjevaca trećoredaca - 50 godišta: 1963. - 2013. Priredio i uredio fra Joso ŽIVKOVIĆ, suradnik fra Mirko MIŠKOVIĆ (Krk, 2014.). 


\section{Friar Stjepan M. Ivančić as a Historian}

Towards the end of the $19^{\text {th }}$ and at the beginning of the $20^{\text {th }}$ century the friar Stjepan Marija Ivančić (Cres, 28 ${ }^{\text {th }}$ August 1852 - Zadar, $8^{\text {th }}$ April 1925), brother of the Third order, occupied a significant place among the historians and chroniclers of the Franciscan movement. Although without a formal education as a historian, he stood out as a dedicated researcher of the monk community to which he himself belonged - the Glagolitic tertiary Franciscans (Tertius Ordo Regularis S. Francisci), and, in general, of the heritage of SS Cyril and Methodius. He published many articles, edited diplomatic and other sources and composed the Imenik preminulih redovnika samostanskog III. reda S.O.F. redodržave s. Jerolima u Dalmaciji, Kvarneru i Istri (Directory of late monks of the monasterial III. order S.O.F. of the province of St. Jerome in Dalmatia, Quarnaro and Istria, 1910) as well as biographies of tertiary writers that were active between the $15^{\text {th }}$ and $19^{\text {th }}$ century (Nešto o hrvatsko-glagolskim piscima samostanskih TrećoredacaSomething about Croatian Glagolitic writers of the monastic tertiaries, 1911). As a crown of his work of many years he published his exceptionally valuable and thorough book Povjestne crte o samostanskom III. Redu sv. O. Franje po Dalmaciji, Kvarneru i Istri i poraba glagolice u istoj redodržavi (Historical notes on the monastic III. order of St. Francis in Dalmatia, Quarnaro and Istria and the usage of Glagolitic script in the same religious province, Zadar 1910). His manuscripts and other writings kept in the Archives of the Provincial administration of tertiary Franciscans in Zagreb and elsewhere are, however, lesser known and utilised and exactly these are the subject of this paper to be presented and evaluated. His work Cronologium seu Historica monumenta Tertii Regularis Ordinis de Poenitentia Sancti Patris Francisci (manuscript in Archivio della Curia Generalizia TOR in Rome) will be described in particular.

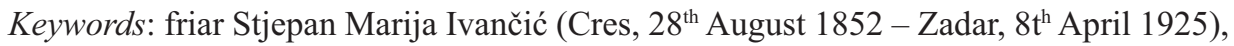
life, work, The Monastic III Order of Holy Father Francis in Croatia, historiography Ključne riječi: fra Stjepan Marija Ivančić (Cres, 28. kolovoza 1852. - Zadar, 8. travnja 1925.), život, djelo, samostanski III. red svetoga oca Franje u Hrvatskoj, historiografija

Tomislav Galović

Filozofski fakultet Sveučilišta u Zagrebu Odsjek za povijest i Zavod za hrvatsku povijest HR-10000 Zagreb, Ivana Lučića 3 tgalovic@ffzg.hr 


\section{FILOZOFSKI FAKULTET SVEUČILIŠTA U ZAGREBU \\ ZAVOD ZA HRVATSKU POVIJEST \\ INSTITUTE OF CROATIAN HISTORY \\ INSTITUT FÜR KROATISCHE GESCHICHTE}
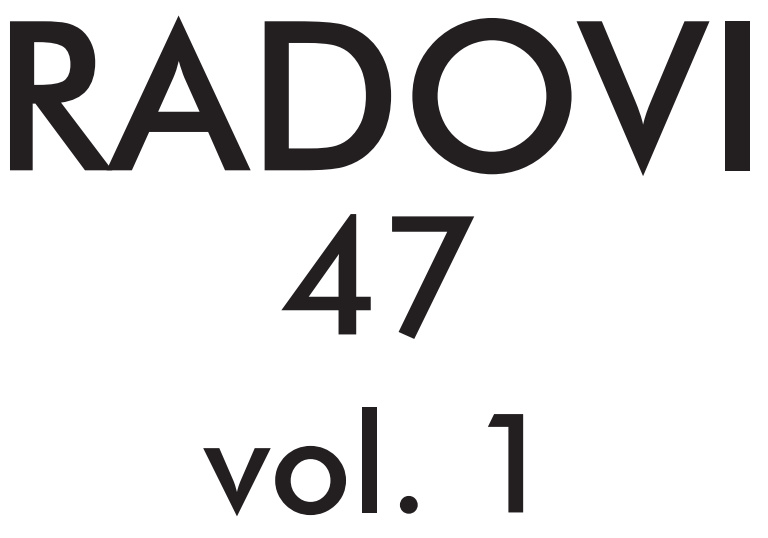

ZAVOD ZA HRVATSKU POVIJEST

FILOZOFSKOGA FAKULTETA SVEUČILIŠTA U ZAGREBU

\section{PF press \\ ZAGREB 2015.}




\title{
RADOVI ZAVODA ZA HRVATSKU POVIJEST FILOZOFSKOGA FAKULTETA SVEUČILIŠTA U ZAGREBU
}

\author{
Knjiga 47, vol. 1
}

\author{
Izdavač / Publisher \\ Zavod za hrvatsku povijest \\ Filozofskoga fakulteta Sveučilišta u Zagrebu \\ FF-press \\ Za izdavača / For Publisher \\ Vlatko Previšić \\ Glavni urednik / Editor-in-Chief \\ Hrvoje Gračanin \\ Izvršna urednica / Executive Editor \\ Inga Vilogorac Brčić \\ Uredništvo / Editorial Board
}

Bruna Kuntić-Makvić (stara povijest/ancient history), Zrinka Nikolić Jakus (srednji vijek/ medieval history), Hrvoje Petrić (rani novi vijek/early modern history), Željko Holjevac (moderna povijest/modern history), Tvrtko Jakovina (suvremena povijest/contemporary history),

Silvija Pisk (mikrohistorija i zavičajna povijest/microhistory and local history),

Zrinka Blažević (teorija i metodologija povijesti/theory and methodology of history)

Međunarodno uredničko vijeće / International Editorial Council

Denis Alimov (Sankt Peterburg), Živko Andrijašević (Nikšić), Csaba Békés (Budapest), Rajko Bratož (Ljubljana), Snježana Buzov (Columbus, Ohio), Svetlozar Eldarov (Sofija), Toni Filiposki (Skopje), Aleksandar Fotić (Beograd), Vladan Gavrilović (Novi Sad), Alojz Ivanišević (Wien),

Egidio Ivetić (Padova), Husnija Kamberović (Sarajevo), Karl Kaser (Graz),

Irina Ognyanova (Sofija), Géza Pálffy (Budapest), Ioan-Aurel Pop (Cluj),

Nade Proeva (Skopje), Alexios Savvides (Kalamata), Vlada Stanković (Beograd), Ludwig Steindorff (Kiel), Peter Štih (Ljubljana)

Izvršna urednica za tuzemnu i inozemnu razmjenu / Executive Editor for Publications Exchange Kristina Milković

Tajnik uredništva / Editorial Board Assistant

Dejan Zadro

Adresa uredništva/Editorial Board address

Zavod za hrvatsku povijest, Filozofski fakultet Zagreb, Ivana Lučića 3, HR-10 000, Zagreb

Tel. ++385 (0)1 6120 150, 6120 158, faks ++385 (0)1 6156879

Časopis izlazi jedanput godišnje / The Journal is published once a year

Časopis je u digitalnom obliku dostupan na / The Journal in digital form is accessible at Portal znanstvenih časopisa Republike Hrvatske „Hrčak“ http://hrcak.srce.hr/radovi-zhp

Financijska potpora za tisak časopisa / The Journal is published with the support by

Ministarstvo znanosti, obrazovanja i športa Republike Hrvatske

Časopis je indeksiran u sljedećim bazama / The Journal is indexed in the following databases:

Directory of Open Access Journals, EBSCO, SCOPUS, ERIH PLUS 
Naslovna stranica

Iva Mandić

Grafičko oblikovanje i računalni slog

Marko Maraković

Lektura

Samanta Paronić

Tisak

Web2tisak, Zagreb

Naklada

250 primjeraka

Časopis je u digitalnom obliku dostupan na Portalu znanstvenih časopisa Republike Hrvatske ,Hrčak“ http://hrcak.srce.hr/radovi-zhp

The Journal is accessible in digital form at the Hrcak - Portal of scientific journals of Croatia http://hrcak.srce.hr/radovi-zhp 


\section{RADOVI 47}

\section{vol. 1}

ZaVoda za hrVAtSku poviJest FILOZOFskoga fakulteta SVeuČILIŠTA u Zagrebu 


\title{
Tematski blok / Themed issue
}

\section{TREĆOREDSKA GLAGOLJAŠKA TRADICIJA U EUROPSKOM KONTEKSTU TERTIARY GLAGOLITIC TRADITION IN EUROPEAN CONTEXT}

\author{
Radovi međunarodnoga znanstvenog skupa \\ održanoga 27. i 28. IX. 2013. na Hrvatskom katoličkom sveučilištu u Zagrebu \\ u organizaciji \\ Provincije franjevaca trećoredaca glagoljaša u Zagrebu, Hrvatskoga katoličkog \\ sveučilišta u Zagrebu, Filozofskoga fakulteta Sveučilišta u Zagrebu - Odsjek za \\ povijest, Filozofskoga fakulteta Sveučilišta u Splitu - Odsjek za povijest, Instituta \\ za povijest umjetnosti u Zagrebu i Staroslavenskoga instituta u Zagrebu \\ Proceedings of the International Scientific Conference \\ held on 27th and 28th September 2013 at the Catholic University of Croatia in Zagreb \\ and organized by \\ the Province of the Glagolitic Friars of the Third Order Regular, Catholic University \\ of Croatia in Zagreb, Faculty of Humanities and Social Sciences of the University \\ of Zagreb - Department of History, Faculty of Humanities and Social Sciences of \\ the University of Split - Department of History, Institute of Art History, \\ and Old Church Slavonic Institute
}

Gosti urednici / Guest editors

\author{
Ivan BOTICA \\ Tomislav GALOVIĆ \\ Kristijan KUHAR
}

